\title{
Contrasting Effects of Al Substitution on Microbial Reduction of Fe(III) (Hydr)oxides
}

\section{Citation}

Ekstrom, Eileen B., Deric R. Learman, Andrew S. Madden, and Colleen M. Hansel. 2010. Contrasting effects of Al substitution on microbial reduction of Fe(III) (hydr)oxides. Geochimica et Cosmochimica Acta 74(24): 7086-7099.

\section{Published Version}

doi:10.1016/j.gca.2010.09.008

\section{Permanent link}

http://nrs.harvard.edu/urn-3:HUL.InstRepos:5342438

\section{Terms of Use}

This article was downloaded from Harvard University's DASH repository, and is made available under the terms and conditions applicable to Other Posted Material, as set forth at http:// nrs.harvard.edu/urn-3:HUL.InstRepos:dash.current.terms-of-use\#LAA

\section{Share Your Story}

The Harvard community has made this article openly available.

Please share how this access benefits you. Submit a story.

Accessibility 


\title{
Contrasting effects of $\mathrm{Al}$ substitution on microbial reduction of $\mathrm{Fe}(\mathrm{III})$ (hydr)oxides
}

\author{
Eileen B. Ekstrom ${ }^{\text {a }}$, Deric R. Learman ${ }^{\mathrm{a}}$, Andrew S. Madden ${ }^{\mathrm{b}}$, Colleen M. Hansel ${ }^{\mathrm{a}, *}$ \\ ${ }^{a}$ Harvard University, School of Engineering and Applied Sciences, Cambridge, MA 02138, USA \\ ${ }^{\mathrm{b}}$ University of Oklahoma, School of Geology and Geophysics, Norman, OK 73019, USA
}

Received 3 September 2010; accepted in revised form 9 September 2010; available online 17 September 2010

\begin{abstract}
Aluminum, one of the most abundant elements in soils and sediments, is commonly found co-precipitated with Fe in natural Fe(III) (hydr)oxides; yet, little is known about how Al substitution impacts bacterial Fe(III) reduction. Accordingly, we investigated the reduction of $\mathrm{Al}$ substituted $(0-13 \mathrm{~mol} \% \mathrm{Al})$ goethite, lepidocrocite, and ferrihydrite by the model dissimilatory $\mathrm{Fe}(\mathrm{III})$-reducing bacterium (DIRB), Shewanella putrefaciens $\mathrm{CN} 32$. Here we reveal that the impact of $\mathrm{Al}$ on microbial reduction varies with $\mathrm{Fe}(\mathrm{III})$ (hydr)oxide type. No significant difference in $\mathrm{Fe}$ (III) reduction was observed for either goethite or lepidocrocite as a function of $\mathrm{Al}$ substitution. In contrast, $\mathrm{Fe}(\mathrm{III})$ reduction rates significantly decreased with increasing $\mathrm{Al}$ substitution of ferrihydrite, with reduction rates of $13 \%$ Al-ferrihydrite more than $50 \%$ lower than pure ferrihydrite. Although Al substitution changed the minerals' surface area, particle size, structural disorder, and abiotic dissolution rates, we did not observe a direct correlation between any of these physiochemical properties and the trends in bacterial Fe(III) reduction. Based on projected Al-dependent Fe(III) reduction rates, reduction rates of ferrihydrite fall below those of lepidocrocite and goethite at substitution levels equal to or greater than $18 \mathrm{~mol} \%$ Al. Given the prevalence of Al substitution in natural $\mathrm{Fe}$ (III) (hydr)oxides, our results bring into question the conventional assumptions about Fe (hydr)oxide bioavailability and suggest a more prominent role of natural lepidocrocite and goethite phases in impacting DIRB activity in soils and sediments.
\end{abstract}

(C) 2010 Elsevier Ltd. All rights reserved.

\section{INTRODUCTION}

Fe(III) oxide, hydroxide, and oxyhydroxide minerals (hence referred to as $\mathrm{Fe}$ (hydr)oxides) such as ferrihydrite $\left(\mathrm{Fe}_{5} \mathrm{HO}_{8} \cdot 4 \mathrm{H}_{2} \mathrm{O}\right)$, lepidocrocite $(\gamma-\mathrm{FeOOH})$, goethite $(\alpha-$ $\mathrm{FeOOH})$, and hematite $\left(\alpha-\mathrm{Fe}_{2} \mathrm{O}_{3}\right)$ are ubiquitous in sediments and soils, contributing up to $50 \%$ of the bulk mass of soils (Schwertmann, 1991). As a result of their high surface areas and density of reactive surface sites, $\mathrm{Fe}$ (III) (hydr)oxides are important sorbents of nutrients $\left(\mathrm{PO}_{4}{ }^{3-}\right.$, $\left.\mathrm{HCO}_{3}{ }^{-}\right)$, trace metals $\left(\mathrm{Co}^{2+}, \mathrm{Cu}^{2+}, \mathrm{Mn}^{2+}, \mathrm{Ni}^{2+}, \mathrm{Zn}^{2+}\right)$, and pollutants (As), playing a critical role in controlling the aquatic chemistry of soils and sediments (Cornell and

\footnotetext{
* Corresponding author.

E-mail address: hansel@seas.harvard.edu (C.M. Hansel).
}

Schwertmann, 2003). After the discovery of bacteria that could conserve energy through the reduction of $\mathrm{Fe}$ (III) (hydr)oxides coupled with organic acid oxidation in the 1980s (Lovley et al., 1987; DiChristina et al., 1988), Fe(III) (hydr)oxides were recognized as an important terminal electron acceptor in anaerobic sediments. Subsequent research found dissimilatory $\mathrm{Fe}(\mathrm{III})$-reducing bacteria (DIRB) to be important in the bioremediation of organic contaminants (Lovley et al., 1989; Lovley, 1997), the sequestration of toxic and radioactive metals (Lloyd, 2003; Wilkins et al., 2006), and the production of electricity in microbial fuel cells (Bretschger et al., 2007; Lovley, 2008).

Given the ecological and environmental importance of bacterial $\mathrm{Fe}(\mathrm{III})$ reduction, a significant amount of research has been conducted determining the rates and solid-phase products of $\mathrm{Fe}(\mathrm{III})$ reduction by DIRB (e.g., Roden and 
Zachara, 1996; Fredrickson et al., 1998; Benner et al., 2002; Ona-Nguema et al., 2002; Zachara et al., 2002; Fredrickson et al., 2003; Glasauer et al., 2003; Hansel et al., 2003, 2004; Ona-Nguema et al., 2004; Behrends and Van Cappellen, 2007; Wilkins et al., 2007; Bose et al., 2009). However, pure $\mathrm{Fe}(\mathrm{III})$ (hydr)oxides are rarely found in natural soils and sediments and instead commonly contain several mol\% substituted ions (Cornell and Schwertmann, 2003). The omnipresence of aluminum as a product of weathering results in most natural Fe(III) (hydr)oxides being Al-substituted (Cornell and Schwertmann, 2003). Aluminum substitution up to $33 \%$ (mole $\mathrm{Al} /$ mole $\mathrm{Al}+\mathrm{Fe}$ ) has been found in natural goethite minerals, up to $16 \%$ in hematite, and up to $9.5 \%$ in lepidocrocite (Wang et al., 1999; Cornell and Schwertmann, 2003). Aluminum co-precipitation in ferrihydrite has been observed in nature and has been synthesized in the lab (Cornell and Schwertmann, 2003) containing up to $20 \mathrm{~mol} \% \mathrm{Al}$ without forming separate $\mathrm{Al}$ phases (Masue et al., 2007). Aluminum substitution can impact the properties of $\mathrm{Fe}(\mathrm{III})$ (hydr)oxides, including changes in unit-cell edge length and volume of the $\mathrm{Fe}(\mathrm{III})$ (hydr)oxide (Cornell and Schwertmann, 2003), average crystallite size, particle morphology, surface area, solubility (Trolard and Tardy, 1987), surface chemistry (Ainsworth et al., 1989), and rates of acid and reductive dissolution (Torrent et al., 1987; Schwertmann, 1991).

Given that Al substitution in Fe(III) (hydr)oxides can significantly change the Fe(III) (hydr)oxides' physical and chemical properties, it is important to understand how $\mathrm{Al}$ substitution will affect bacterial Fe(III) reduction and dissolution. To date, there are no published studies exploring the effects of Al substitution within ferrihydrite or lepidocrocite on bacterial reduction. Results from four published studies on the bacterial reduction and dissolution of Al-goethites found contrasting results, with $\mathrm{Al}$ substitution resulting in decreased Fe(III) reduction (Bousserrhine et al., 1999; Dominik et al., 2002), increased microbial productivity (Maurice et al., 2000), or no substantial change in the extent and rate of reduction (Kukkadapu et al., 2001). These findings highlight the need for a broader investigation of the impact of $\mathrm{Al}$ substitution within $\mathrm{Fe}(\mathrm{III})$ (hydr)oxides on microbial $\mathrm{Fe}(\mathrm{III})$ reduction.

Accordingly, we explored the role of $\mathrm{Al}$ substitution on controlling the rate and extent of reduction of synthetic ferrihydrite, lepidocrocite, and goethite minerals containing between 0 and $13 \mathrm{~mol} \% \mathrm{Al}$ by a model DIRB, Shewanella putrefaciens strain CN32. Considering the prevalence of Al substitution within $\mathrm{Fe}(\mathrm{III})$ (hydr)oxides, determining the impact of substitution on microbial Fe(III) reduction will have broad relevance for predicting the reducing capacity of sediments and controls on Fe(III)-based remediation strategies.

\section{EXPERIMENTAL METHODS AND PROCEDURES}

\subsection{Synthesis of $\mathrm{Fe}(\mathrm{III})$ (hydr)oxides}

We synthesized and purified 2-line ferrihydrite $\left(\mathrm{Fe}_{5} \mathrm{HO}_{8} \cdot 4 \mathrm{H}_{2} \mathrm{O}\right)$, lepidocrocite $(\gamma-\mathrm{FeOOH})$, and goethite $(\alpha-\mathrm{FeOOH})$ containing between 0 and $13 \mathrm{~mol} \% \mathrm{Al}$ [mole
$\mathrm{Al} /($ mole $\mathrm{Fe}+$ mole $\mathrm{Al})]$. To minimize other co-precipitates in the $\mathrm{Fe}(\mathrm{III})$ (hydr)oxides, all mineral syntheses were conducted with acid-washed equipment, and all stocks were made in acid-washed, glass containers with double deionized water and ACS grade chemicals. Four ferrihydrite mineral phases containing $0,3,9$, and $13 \mathrm{~mol}^{\%} \mathrm{Al}$ were created by first combining $0.2 \mathrm{M} \mathrm{FeCl}{ }_{3}$ stock with a $0.2 \mathrm{M}$ $\mathrm{Al}\left(\mathrm{NO}_{3}\right)_{3}$ stock in proportion to the final $\mathrm{Al} \mathrm{mol} \%$, to a final volume of $500 \mathrm{~mL}$. The solutions were then rapidly titrated with $1 \mathrm{M} \mathrm{KOH}$ to a $\mathrm{pH}$ of 7.5 , followed by centrifugation and dialysis to remove any contaminants (Schwertmann and Cornell, 2000). The Fe(III) (hydr)oxides were dialyzed using Spectra/Por cellulose dialysis tubing (MWCO 12,000 to 14,000 ) until a steady conductivity value was obtained.

Al-substituted lepidocrocite (0, 3, 10, and $13 \mathrm{~mol} \%$ ) were produced by a controlled oxidation of ferrous chloride salt and aluminum nitrate in a $\mathrm{NH}_{3} / \mathrm{NH}_{4} \mathrm{Cl}$ buffer with $\mathrm{CO}_{2}$ free air at $\mathrm{pH} 8$ and a temperature of $13-15^{\circ} \mathrm{C}$ (Schwertmann and Wolska, 1990). $\mathrm{FeCl}_{2}$ and $\mathrm{Al}\left(\mathrm{NO}_{3}\right)_{3}$, added in proportion to the final $\mathrm{mol}_{\%} \% \mathrm{Al}$, were dissolved in $300 \mathrm{~mL}$ of $0.2 \mathrm{M} \mathrm{NH} \mathrm{NH}_{3} / \mathrm{NH}_{4} \mathrm{Cl}$ buffer $(50 \mathrm{~mL} 0.2 \mathrm{M}$ $\mathrm{NH}_{4} \mathrm{OH}$ and $950 \mathrm{~mL} 0.2 \mathrm{M} \mathrm{NH} \mathrm{NCl}_{4}$ ) in a $600 \mathrm{~mL}$ jacketed beaker placed on top of a stir plate and attached to a continuous-flow chiller. The $\mathrm{pH}$, which was continuously monitored, was initially adjusted with $1 \mathrm{M} \mathrm{NH}_{3}$ to a $\mathrm{pH}$ of 8.0, after which $\mathrm{CO}_{2}$-free air was introduced in the solution through a fritted glass gas-dispersion tube. During the ferrous chloride oxidation, the $\mathrm{pH}$ was held at $8.00 \pm 0.05$ with the addition of $1 \mathrm{M} \mathrm{NH}_{3}$ and the temperature was held between 13 and $15^{\circ} \mathrm{C}$ for approximately $1.5 \mathrm{~h}$. Counter anions were subsequently removed by dialysis.

Goethite substituted with $0,2,4$, and $6 \mathrm{~mol} \%$ aluminum were synthesized by incubating freshly made Al-ferrihydrite in an alkaline system at $70^{\circ} \mathrm{C}$ for 14 days, followed by a $1 \mathrm{M} \mathrm{KOH}$ wash and dialysis (Schwertmann and Cornell, 2000). Residual ferrihydrite was removed from the goethite mineral slurries by 5 rinses with $0.25 \mathrm{M} \mathrm{NH}_{2} \mathrm{OH}$ in $0.25 \mathrm{M}$ $\mathrm{HCl}$, incubated at $50{ }^{\circ} \mathrm{C}$ for 5 periods of $30 \mathrm{~min}$, followed by centrifugation, and finally dialysis (Zachara et al., 2001). All mineral slurries were stored at $4{ }^{\circ} \mathrm{C}$.

A subset of Al-doped ferrihydrite minerals were coated on quartz sand following the method of Brooks et al. (1996) and as conducted previously (Hansel et al., 2003, 2004). Pure quartz sand (Unimin Corporation) was mixed with ferrihydrite slurry (10 mg Al-ferrihydrite per g quartz sand), excess water was decanted, and the mixture was allowed to evaporate at room temperature under convection with periodic stirring. The coated sand was dried, washed with DI water to remove ferrihydrite not attached to the sand, and dried for 3 days. Ferrihydrite-coated sands were sterilized by gamma irradiation $(25 \mathrm{kGy}$, by Food Technology Service Inc., Mulberry, FL).

\subsection{Mineral characterization}

The identity and purity of the 12 synthetic minerals were confirmed using X-ray diffraction (XRD) and extended Xray absorption fine structure (EXAFS) spectroscopy. XRD was conducted on a Scintag XDS2000 with $\mathrm{CuK} \alpha$ 
radiation (Department of Chemistry and Chemical Biology at Harvard University). EXAFS spectra were acquired at the Stanford Synchrotron Radiation Laboratory (SSRL) on beamline 11-2. Spectra acquisition and analyses followed the procedures previously described in detail (Benner et al., 2002; Hansel et al., 2003, 2004). Purity was confirmed by comparing the synthesized phases to reference standards for ferrihydrite, lepidocrocite, and goethite. Linear combination $k^{3}$-weighted EXAFS (LC-EXAFS) spectral fitting was also conducted on lepidocrocite and goethite samples to define the fractional abundance of ferrihydrite within the samples, serving as a proxy for phase disorder (Hansel et al., 2004). LC-EXAFS was conducted using SIXpack (Webb, 2005).

The $\mathrm{Fe}$ and $\mathrm{Al}$ content of the minerals were determined by dissolving $1 \mathrm{~mL}$ of the mineral slurries in $2 \mathrm{~mL}$ concentrated $\mathrm{HCl}$ followed by dilution with double deionized water and $\mathrm{Fe}$ and $\mathrm{Al}$ analysis by ICP. Throughout the manuscript, the $\mathrm{mol} \% \mathrm{Al}$ of all minerals is based on their measured $\mathrm{Al}$ and $\mathrm{Fe}$ content. Mineral surface area was determined with a BET analyzer (Beckman Coulter SA 3100) after degassing for $24 \mathrm{~h}$ at $25^{\circ} \mathrm{C}$. Particle size and shape of the minerals were determined by transmission electron microscopy (TEM) analysis. Dried, powdered samples for TEM analysis were diluted in double deionized water, ultrasonicated for $15 \mathrm{~min}$, and placed on carbon/formvar supported copper grids until the liquid evaporated. Samples were analyzed on a JEOL 2000-FX TEM (University of Oklahoma's Samuel Roberts Noble Electron Microscopy Laboratory).

Acid dissolution experiments with the mineral slurries were conducted to better understand the dissolution properties of the Al-containing minerals and to determine if Al co-precipitation occurred congruently or incongruently. For ferrihydrite minerals, $50 \mathrm{mg}$ of the slurry was added to $100 \mathrm{~mL}$ of $0.1 \mathrm{M} \mathrm{HCl} .50 \mathrm{mg}$ of lepidocrocite minerals were added to $100 \mathrm{~mL}$ of $0.5 \mathrm{M} \mathrm{HCl}$, and for goethite, $250 \mathrm{mg}$ of the mineral slurry was added to $6 \mathrm{M} \mathrm{HCl}$. All dissolution experiments were conducted at room temperature and shaken at $200 \mathrm{rpm}$, since previous research demonstrated that at this speed and above, dissolution is not diffusion controlled but instead depends solely on the surface reaction rate (Cornell et al., 1974). The dissolution experiments were sampled 10 times for dissolved metals $(5 \mathrm{~mL}$ passed through a $0.2 \mu \mathrm{m}$ filter $)$ and total metals $(2 \mathrm{~mL}$ digested in $6 \mathrm{M} \mathrm{HCl}$ ). Diluted samples were analyzed for $\mathrm{Fe}$ and Al concentration by ICP.

\subsection{Bacterial medium and preparation of cultures}

Iron(III) reduction batch experiments were conducted in anaerobic medium with a $\mathrm{pH}$ of 7.0 modified from Fredrickson et al. (1998). The medium contained $18 \mathrm{mM}$ sodium lactate, $4.7 \mathrm{mM} \mathrm{NH} \mathrm{NH}_{4} \mathrm{Cl} 1.2 \mathrm{mM} \mathrm{KCl}, 0.61 \mathrm{mM} \mathrm{CaCl}_{2}$, $1.1 \mathrm{mM} \mathrm{MgSO}, 1.5 \mathrm{mM} \mathrm{NaCl}, 4.5 \mathrm{mM}$ PIPES, $0.4 \mathrm{mM}$ $\mathrm{NaH}_{2} \mathrm{PO}_{4}$. A $1 \mathrm{~L}$ batch of the medium was amended with $1 \mathrm{~mL}$ of an acidified trace metal stock (excluding NTA) based on Widdel and Bak (1992) and $0.1 \mathrm{~mL}$ of a concentrated vitamin stock (Widdel and Bak, 1992). The trace metal stock, made in $0.05 \% \mathrm{HCl}$ contained $0.5 \mathrm{mM} \mathrm{H}_{3} \mathrm{BO}_{3}$,
$0.5 \mathrm{mM} \mathrm{MnCl} 2,0.8 \mathrm{mM} \mathrm{CoCl} 2,0.1 \mathrm{mM} \mathrm{NiCl}_{2}, 0.01 \mathrm{mM}$ $\mathrm{CuCl}_{2}, \quad 0.5 \mathrm{mM} \quad \mathrm{ZnSO}_{4}, \quad 0.15 \mathrm{mM} \quad \mathrm{Na}_{2} \mathrm{MoO}_{4}, \quad$ and $0.02 \mathrm{mM} \mathrm{Na}_{2} \mathrm{SeO}_{3}$. The concentrated vitamin stock contained $100 \mathrm{mg}$ 4-aminobenzoic acid, $100 \mathrm{mg} \mathrm{D(+)-biotin,}$ $100 \mathrm{mg}$ nicotinic acid, $100 \mathrm{mg}$ calcium $\mathrm{D}(+)$-pantothenate, $100 \mathrm{mg}$ pyridoxine $\mathrm{HCl}, 100 \mathrm{mg}$ thiamine hydrochloride, $100 \mathrm{mg}$ riboflavin, $100 \mathrm{mg}$, folic acid, $100 \mathrm{mg}$ niacinamide, $100 \mathrm{mg}$ thiamine pyrophosphate, and $50 \mathrm{mg}$ vitamin $\mathrm{B}_{12}$ in $100 \mathrm{~mL} \mathrm{H}_{2} \mathrm{O}$. The medium was boiled under a stream of $\mathrm{O}_{2}$-free $\mathrm{N}_{2}$ gas for $10 \mathrm{~min}$ to sparge out any oxygen and subsequently dispensed into anaerobic Balch tubes or serum bottles using the Hungate method (Widdel and Bak, 1992) and autoclaved.

Bacterial Fe(III) reduction experiments were conducted with $S$. putrefaciens strain CN32, a facultative, dissimilatory $\mathrm{Fe}(\mathrm{III})$-reducing bacterium (DIRB), (Fredrickson et al., 1997, 1998) that couples the oxidation of lactate to acetate with $\mathrm{Fe}(\mathrm{III})$ reduction. Cultures were prepared for experiments according to the methods described in Hansel et al. (2004). Late log phase cells $\left(\sim 3 \times 10^{9}\right.$ cells $\left./ \mathrm{mL}\right)$ grown in TSB were harvested by centrifugation $(4500 \mathrm{rpm}, 10 \mathrm{~min}$, $10^{\circ} \mathrm{C}$ ), washed twice in $100 \mathrm{~mL}$ sterile phosphate buffer solution (130 mM NaCl, $7 \mathrm{mM} \mathrm{Na} \mathrm{HPO}_{4}, 3 \mathrm{mM} \mathrm{NaH}$ $\mathrm{PO}_{4}, \mathrm{pH}$ 7.2), and resuspended in $10 \mathrm{~mL}$ of anaerobic medium in an anaerobic chamber (Coy Laboratories Inc., Grass Lake, MI) under $90 \% \mathrm{~N}_{2} / 10 \% \mathrm{H}_{2}$ gas.

\subsection{Bacterial Fe reduction experimental design and analysis}

Batch reduction experiments were run in duplicate in $25 \mathrm{~mL}$ balch tubes containing $15 \mathrm{mg}$ Fe of the mineral with anaerobic medium added up to $15 \mathrm{~mL}(1 \mathrm{mg} \mathrm{Fe} / \mathrm{mL})$. Prior to experiments, the mineral slurries were added to sterile balch tubes, bubbled with $\mathrm{O}_{2}$-free $\mathrm{N}_{2}$ gas for $30 \mathrm{~min}$, sealed, flushed with $0.2 \mu \mathrm{m}$ filtered $\mathrm{N}_{2}$ gas with sterile needles, and autoclaved for 15 min (Straub et al., 2005). Anaerobic medium was added sterilely using the Hungate method. All treatments were inoculated with $0.1 \mathrm{~mL}$ of a concentrated cell culture $\left(\sim 3 \times 10^{9}\right.$ cells $)$ within a time span of $15 \mathrm{~min}$, resulting in a final cell concentration of $\sim 2 \times 10^{7}$ cells $/ \mathrm{mL}$ within each vial. For the duration of the 20 day experiment, treatments were shaken on their side at $115 \mathrm{rpm}$ at room temperature. $\mathrm{Fe}(\mathrm{II})$ and acetate production was measured over the length of the 20 day incubation. Monitoring the concentration of acetate, produced through the microbial consumption of $1 \mathrm{~mol}$ of lactate coupled with the reduction of $4 \mathrm{~mol}$ of $\mathrm{Fe}$ (III), helped confirm the trends observed with the $\mathrm{Fe}(\mathrm{III})$ reduction data. The experimental treatments were sampled 8 times by vigorously shaking the tube and immediately extracting the slurry using a sterile syringe in an anaerobic chamber. To decrease any potential oxidation of $\mathrm{Fe}(\mathrm{II})$, subsamples for metal analysis were immediately dispensed into glass scintillation vials containing $1 \mathrm{~mL}$ of concentrated $\mathrm{HCl}$. The efficiency of $\mathrm{HCl}(1 \mathrm{~N}$ and higher) in completely dissolving secondary phases (e.g., green rust, siderite, magnetite) following bioreduction of ferrihydrite has been previously confirmed (Fredrickson et al., 1998; Benner et al., 2002). The mineral extracts were shaken for a maximum of $24 \mathrm{~h}$ and subsequently analyzed for $\mathrm{Fe}(\mathrm{II})$. Samples for organic acid analysis were immediately frozen. 
Bioreduction experiments with Al-ferrihydrite coated sand were designed and sampled with comparable methods as described for the mineral slurry bioreduction experiments. One gram of sterilized sand (coated with $10 \mathrm{mg}$ of ferrihydrite) was added to each balch tube containing $10 \mathrm{~mL}$ of autoclaved anaerobic media in the anaerobic chamber using sterile techniques. To sample the bioreduction experiment for $\mathrm{Fe}$ reduction, duplicate tubes were sacrificed for analysis at each timepoint. In the anaerobic chamber, the liquid suspension was filtered with a $0.45 \mu \mathrm{m}$ filter, and analyzed for dissolved Fe(II) (ferrozine assay; Stookey, 1970), organic acids (IC), and dissolved $\mathrm{Fe}$ and $\mathrm{Al}$ (ICP). The ferrihydrite coated sand was rinsed with sterile and anaerobic double deionized water and used for solid $\mathrm{Fe}(\mathrm{II})$ analysis.

Total Fe(II) in extracts was determined using the ferrozine assay (Stookey, 1970), adding $0.1 \mathrm{~mL}$ of the extract to $9.9 \mathrm{~mL}$ of ferrozine reagent in the anaerobic chamber. To determine the concentration of acetate produced by the $S$. putrefaciens during Fe reduction, subsamples were run on a Dionex IC (ICS-2000) with eluent generation on AG11HC column following Dionex Application Note 123. Prior to analysis, samples were diluted 100 -fold with sterile water due to high lactate levels and filtered with a $0.4 \mu \mathrm{m}$ filter. Total $\mathrm{Fe}$ and $\mathrm{Al}$ concentrations were determined on diluted acid extracts on a Jobin Yvon ICP (D. Schrag Lab, Harvard University).

\section{RESULTS AND DISCUSSION}

\subsection{Impact of Al substitution on mineral physiochemical properties}

To determine the role of $\mathrm{Al}$ substitution in altering bacterial $\mathrm{Fe}(\mathrm{III})$ reduction, we synthesized ferrihydrite containing $0,3,9$, and $13 \mathrm{~mol} \% \mathrm{Al}$ [mole $\mathrm{Al} /($ mole $\mathrm{Fe}+$ mole $\mathrm{Al})$ ], lepidocrocite containing $0,3,10$, and $13 \mathrm{~mol} \% \mathrm{Al}$, and goethite containing $0,2,4$, and $6 \mathrm{~mol} \% \mathrm{Al}$. The identity of the synthesized phases was confirmed using X-ray diffraction (XRD) and extended X-ray absorption fine structure (EXAFS) spectroscopy. Peaks indicative of ferrihydrite, goethite, and lepidocrocite were identified in the XRD spectra (Fig. 1). Substantial differences between the XRD patterns were not evident for ferrihydrite and goethite as a function of Al substitution. However, Al substitution in lepidocrocite leads to a subtle shift in diffraction peaks towards lower $2 \theta$ degrees as observed previously (Schwertmann and Wolska, 1990). Defining changes in the unit cell, however, is complicated due to the broadening of XRD lines with increasing Al content (Taylor and Schwertmann, 1980). Previously, Al substitution in lepidocrocite led to a contraction in the unit cell size, with a linear decrease in the unit cell edge lengths $a, b$, and $c$ with increasing $\mathrm{Al}$ content (Schwertmann and Wolska, 1990). Here, we also see the (200), (511), and (521) reflections (0.627, 0.174, and $0.137 \mathrm{~nm}$, respectively) disappear at the higher Al levels for lepidocrocite. For all of the $\mathrm{Fe}$ (III) (hydr)oxides, no other peaks indicative of separate aluminum phases were observed in the diffraction data.
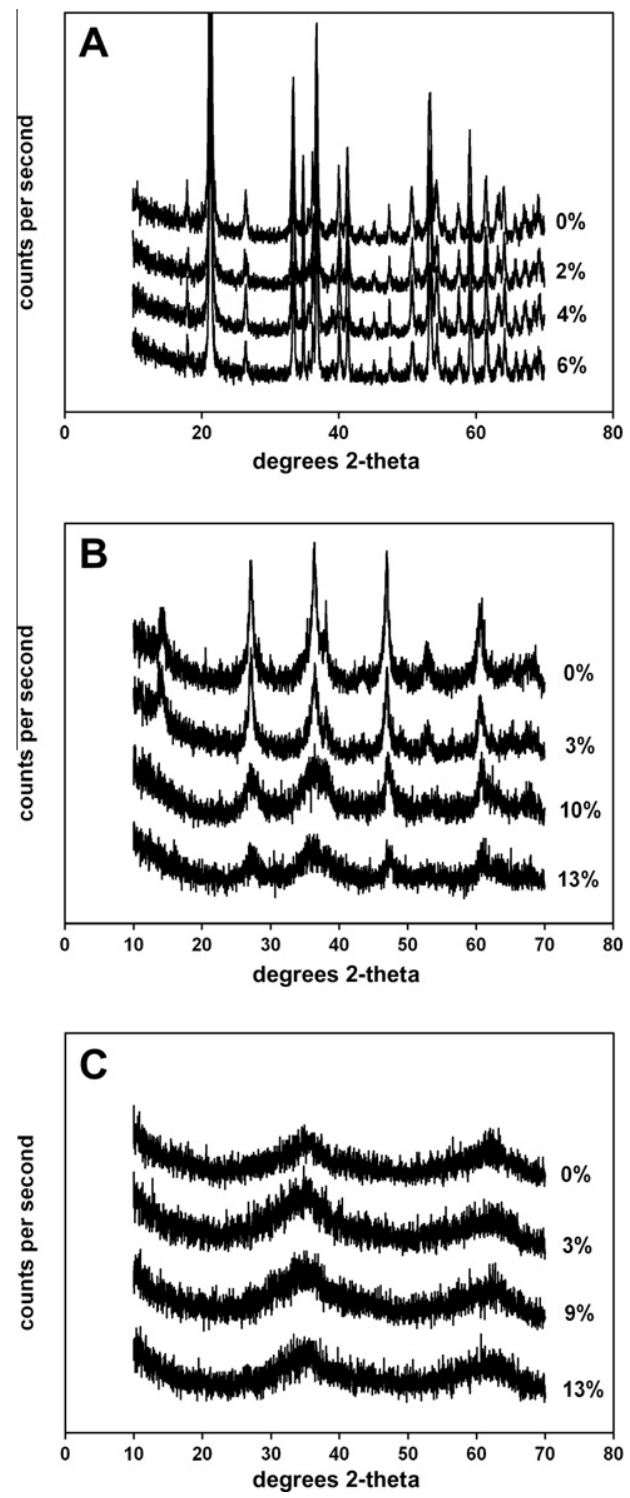

Fig. 1. X-ray diffraction patterns for pure and substituted (A) goethite, (B) lepidocrocite, and (C) ferrihydrite.

Comparison of the pure and substituted (hydr)oxide $k^{3}$ weighted EXAFS spectra further confirms the identity of the substituted phases (Fig. 2). Similar to the observed increase in disorder for the lepidocrocite XRD spectra, a dampening of the lepidocrocite EXAFS spectra (Fig. 2; Supplementary information Fig. S1) is indicative of a decrease in the long-range order of the Al-substituted phases, which may be attributed to changes in the size or order of the precipitates as discussed further below. Although the pure and substituted goethites are similar, slight differences in the high $k$ region of the EXAFS spectra are evident (Fig. 2; Supplementary information Fig. S2), suggesting that there are some structural differences between the phases warranting further investigation beyond the scope of this study. There are no observable differences in the EXAFS spectra for the pure and substituted ferrihydrites. 


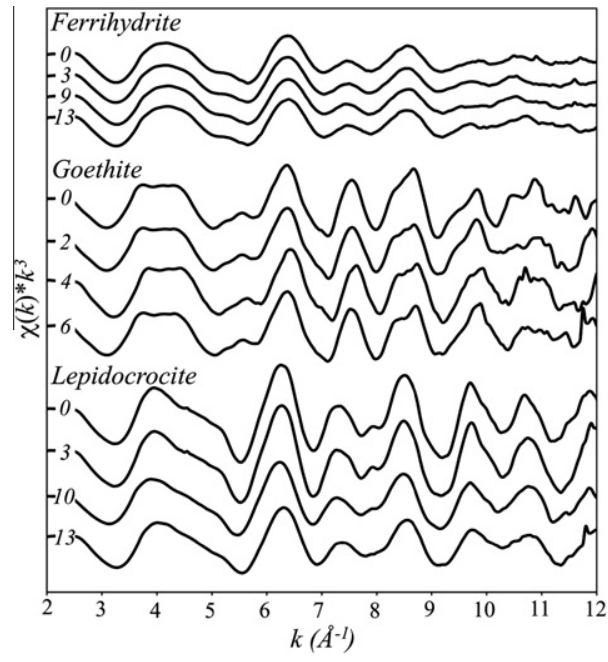

Fig. 2. $k^{3}$-Weighted EXAFS spectra for pure and substituted $\mathrm{Fe}$ (III) (hydr)oxides. The percent $\mathrm{Al}$ is indicated on the left side of each spectra.

In acid dissolution experiments, all minerals dissolved congruently (Fig. 3), indicating that both $\mathrm{Al}$ and Fe dissolved at equal rates. Congruent dissolution is indicative of isomorphic substitution, in which $\mathrm{Al}$ is dispersed throughout the entire mineral phase instead of becoming concentrated on the surface or as discrete domains within the (hydr)oxide (Cornell and Schwertmann, 2003).

Aluminum substitution impacted the physicochemical properties of the $\mathrm{Fe}(\mathrm{III})$ (hydr)oxides, including acid dissolution, surface area, particle size, and morphology. In regards to the acid dissolution behavior of the (hydr)oxides, since dissolution curves were sigmoidal, a modified first order rate law (Kabai equation) was used to determine the rate constant of dissolution, $k\left(\mathrm{~min}^{-1}\right)$ (Table 1$)$, as previously done for Al-substituted Fe(III) (hydr)oxides (Kabai, 1973; Schwertmann, 1991; Alvarez et al., 2007). The Kabai equation is expressed in its linear form as $\ln \ln [1 /(1-$ $\left.\left.\mathrm{c}_{\mathrm{Fe}}\right)\right]=\ln k+\alpha \ln t$, where $\mathrm{c}_{\mathrm{Fe}}$ is the fraction of $\mathrm{Fe}$ dissolved at time $(t), k$ is the dissolution rate constant, and $\alpha$ is a fitting coefficient, which is characteristic of the structure of the solid-phase (Kabai, 1973; Schwertmann et al., 1985). Al substitution in the three Fe(III) (hydr)oxides affected acid dissolution in different ways. Al substitution in goethite resulted in minerals more resistant to acid dissolution since the dissolution rate constants sequentially decrease with increasing $\mathrm{Al}$ and show a 4.1 times decrease in the rate for the highest Al level (6\%) compared to unsubstituted goethite. These results are consistent with previous findings for goethite containing up to $12 \mathrm{~mol} \% \mathrm{Al}$ (Alvarez et al., 2007; Schwertmann, 1984; Torrent et al., 1987). In contrast, increasing $\mathrm{Al}$ substitution in lepidocrocite resulted in faster acid dissolution, as shown by the higher dissolution rate constants at high $\mathrm{Al}$ concentrations, up to 5.8 times faster for $13 \% \mathrm{Al}$ lepidocrocite compared to the pure phase. The difference in dissolution behavior between lepidocrocite and goethite has been previously attributed, in part, to the impact of $\mathrm{Al}$ on the strength of the hydrogen bond due to crystallinity changes. In brief, an increase in $\mathrm{OH}$-stretch fre-
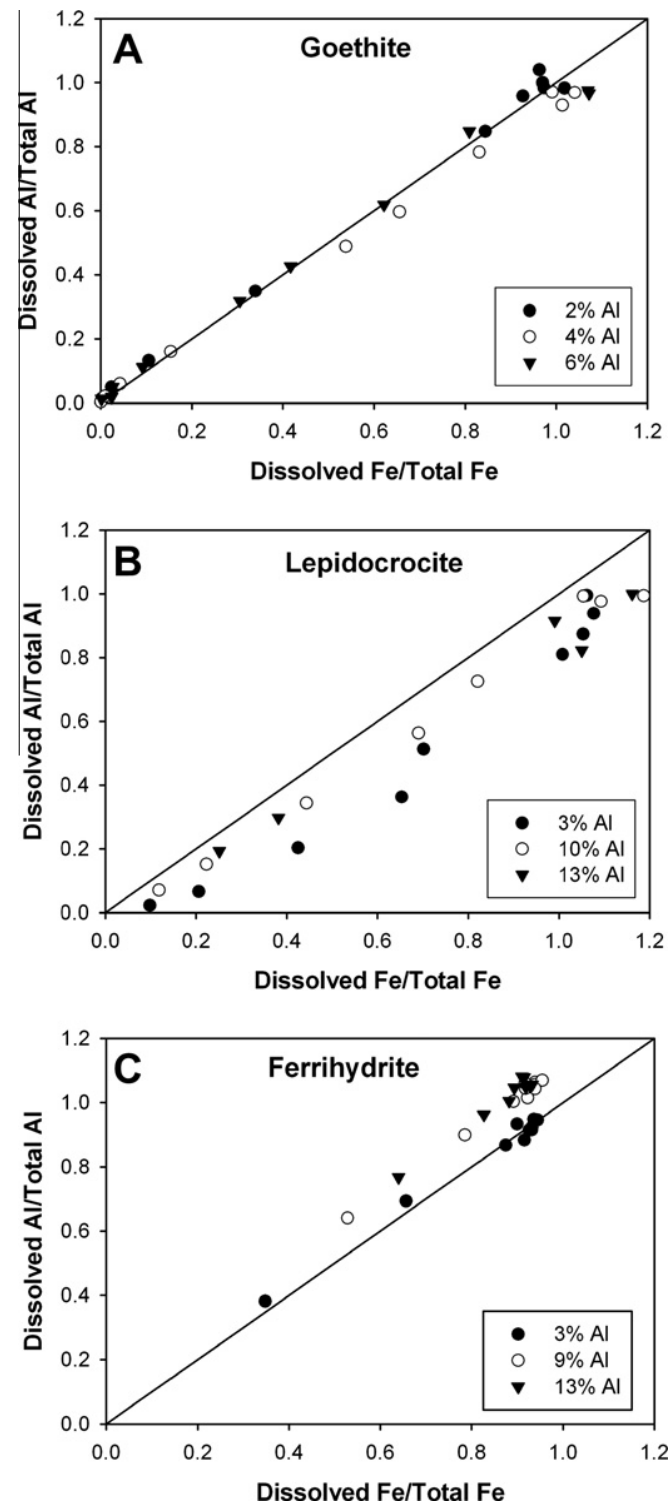

Fig. 3. Ratio of dissolved $\mathrm{Al}$ to total $\mathrm{Al}$ in mineral versus dissolved $\mathrm{Fe}$ to total $\mathrm{Fe}$ in mineral released during acid dissolution experiments of goethite (A), lepidocrocite (B), and ferrihydrite (C). The line represents ideal congruent dissolution.

quency and decrease in out-of-plane bending frequency was observed for lepidocrocite, which was opposite to those observed for Al substituted goethites (Schulze and Schwertmann, 1984, 1987; Schwertmann and Wolska, 1990). Acid dissolution rate constants varied little (maximum 1.4 times) with increasing $\mathrm{Al}$ in ferrihydrite, indicating that Al-substitution did not substantially change the dissolution properties of ferrihydrite.

Surface area did not change substantially for ferrihydrite and only slightly decreased for goethite with increasing $\mathrm{Al}$ substitution (Table 2). Previous research by Gonzalez et al. (2002) also found that the surface area of goethite did not change considerably with Al substitution. In contrast, however, Al substitution within lepidocrocite resulted in a substantial increase in surface area - increasing from 
Table 1

Acid dissolution rate constants using the Kabai equation.

\begin{tabular}{lccc}
\hline Sample & Rate constant $k\left(\mathrm{~min}^{-1}\right)$ & $\alpha$ & $R^{2}$ \\
\hline Goethite (250 mg in $100 \mathrm{~mL} \mathrm{6} \mathrm{M} \mathrm{HCl})$ & & \\
0\% Al goethite & 0.00135 & 1.342 & 0.996 \\
2\% Al goethite & 0.00101 & 1.264 & 0.998 \\
4\% Al goethite & 0.00101 & 1.423 & 0.996 \\
6\% Al goethite & 0.00033 & 1.325 & 0.999 \\
Lepidocrocite (50 mg Fe in $100 \mathrm{~mL} 0.5 \mathrm{M} \mathrm{HCl})$ & & \\
0\% Al lepidocrocite & 0.00357 & 0.680 & 0.995 \\
3\% Al lepidocrocite & 0.00499 & 0.774 & 0.985 \\
10\% Al lepidocrocite & 0.00567 & 0.643 & 0.999 \\
13\% Al lepidocrocite & 0.02071 & 0.719 & 0.886 \\
Ferrihydrite (50 mg Fe in $100 \mathrm{~mL} 0.1 \mathrm{M} \mathrm{HCl})$ & & \\
0\% Al ferrihhydrite & 0.10056 & 1.275 & 0.972 \\
3\% Al ferrihydrite & 0.07296 & 1.190 & 0.982 \\
9\% Al ferrihydrite & 0.07849 & 1.107 & 0.999 \\
13\% Al ferrihydrite & 0.08909 & 0.773 & 0.979 \\
\hline
\end{tabular}

144 to $255 \mathrm{~m}^{2} \mathrm{~g}^{-1}$ with the incorporation of $13 \mathrm{~mol} \% \mathrm{Al}$ (Table 2). The change in surface area is likely a consequence of a number of factors as discussed below, including particle size, morphology, crystallinity, and/or presence of ferrihydrite.

Mineral particle dimensions measured by TEM mirror the surface area trends, with increasing surface area correlating with decreasing particle size. Typical particle dimensions of $13 \%$ Al-lepidocrocite decreased over 50 times relative to $0 \%$ Al-lepidocrocite (Table 2, Fig. 4E anf F). Schwertmann and Wolska (1990) also observed a decrease in particle size with Al substitution (up to 10\%) of lepidocrocite. In contrast, the typical particle dimensions mea- sured for $6 \%$ Al-goethite was only 2 times smaller than $0 \%$ Al-goethite (Table 2). No observable changes to particle dimensions were found for Al-containing ferrihydrite (Table 2).

Aluminum substitution also modified particle morphology for lepidocrocite and goethite. Goethite particles without $\mathrm{Al}$ were multidomanic acicular crystals, while $6 \% \mathrm{Al}-$ goethite had more monodomainic crystals (Fig. 4C and D) with a decrease in the aspect ratio relative to $0 \% \mathrm{Al}$-goethite (Table 2). Similar trends have been previously observed for Al-substituted goethite (Gonzalez et al., 1987; Schulze and Schwertmann, 1987) and lepidocrocite (Schwertmann and Wolska, 1990). The most pronounced change due to Al substitution was observed in lepidocrocite. Without Al-doping, blocky laths volumetrically dominate sample morphology (Fig. 4E). However, small blocky and $<10 \mathrm{~nm}$ rounded particles are numerically abundant (Supplementary information Fig. S3). Morphology of the 13\% Al lepidocrocite (Fig. 4F) consist of extremely thin "crumpled sheets" (Kassim et al., 1982) with $<10 \mathrm{~nm}$ rounded particles. Linear structures observed in the TEM (Supplementary information Fig. S4 also) may represent curved or folded edges of sheets or perhaps thin filaments elongated along the chains of Fe octahedra.

The results of the XRD (Fig. 1), EXAFS (Fig. 2), and acid dissolution (Fig. 3) analyses indicate that Al substitution may change the crystallinity of the Fe(III) (hydr)oxide, which is particularly evident for lepidocrocite. The impact of $\mathrm{Al}$ on the crystallinity of the synthetic lepidocrocite and goethite was determined by LC-EXAFS using ferrihydrite as a proxy for disorder within the phases (Hansel et al., 2004). The ferrihydrite component within lepidocrocite increased with Al substitution, with the fraction of ferrihydrite

Table 2

Mineral surface area, particle size, and morphology.

\begin{tabular}{|c|c|c|c|}
\hline Sample & $\begin{array}{l}\text { Surface area } \\
\left(\mathrm{m}^{2} \mathrm{~g}^{-1}\right)\end{array}$ & $\begin{array}{l}\text { Particle dimensions } \\
(\mathrm{nm})^{\mathrm{a}, \mathrm{b}}\end{array}$ & Particle morphology ${ }^{\mathrm{a}}$ \\
\hline $0 \% \mathrm{Al}$ goethite & 41 & $88 \pm 29 \times 551 \pm 193$ & Multidomanic acicular crystals \\
\hline $2 \% \mathrm{Al}$ goethite & 45 & - & \\
\hline $4 \% \mathrm{Al}$ goethite & 39 & - & \\
\hline $6 \% \mathrm{Al}$ goethite & 36 & $66 \pm 13 \times 340 \pm 68$ & $\begin{array}{l}\text { Acicular crystals with a decrease in aspect ratio and multidomanic } \\
\text { crystals }\end{array}$ \\
\hline $\begin{array}{l}0 \% \mathrm{Al} \\
\text { lepidocrocite }\end{array}$ & 144 & $46 \times 280$ & $\begin{array}{l}\text { Blocky lath-shaped particles with trace ferrihydrite. Highly } \\
\text { polydisperse }\end{array}$ \\
\hline $\begin{array}{l}3 \% \mathrm{Al} \\
\text { lepidocrocite }\end{array}$ & 131 & - & \\
\hline $\begin{array}{l}10 \% \mathrm{Al} \\
\text { lepidocrocite }\end{array}$ & 216 & - & \\
\hline $\begin{array}{l}13 \% \mathrm{Al} \\
\text { lepidocrocite }\end{array}$ & 255 & $3 \times 10$ to $5 \times 50$ & $\begin{array}{l}\text { Small laths with subrounded grains that mimic size \& morphology } \\
\text { of ferrihydrite }\end{array}$ \\
\hline $0 \% \mathrm{Al}$ ferrihydrite & 314 & $<5$ & Small aggregated spheres \\
\hline $3 \% \mathrm{Al}$ ferrihydrite & 329 & - & \\
\hline $9 \% \mathrm{Al}$ ferrihydrite & 318 & - & \\
\hline $13 \% \mathrm{Al}$ ferrihydrite & 328 & $<5$ & Small aggregated spheres \\
\hline
\end{tabular}

\footnotetext{
${ }^{a}$ Particle dimensions and morphology determined by TEM on only mineral samples containing the least and most substituted Al for each mineral type.

${ }^{\mathrm{b}}$ Number of particles used in particle dimension calculations were (top to bottom): 21,63 , and 7 . Values for $13 \%$ lepidocrocite are highly approximate due to the poorly defined morphology.
} 

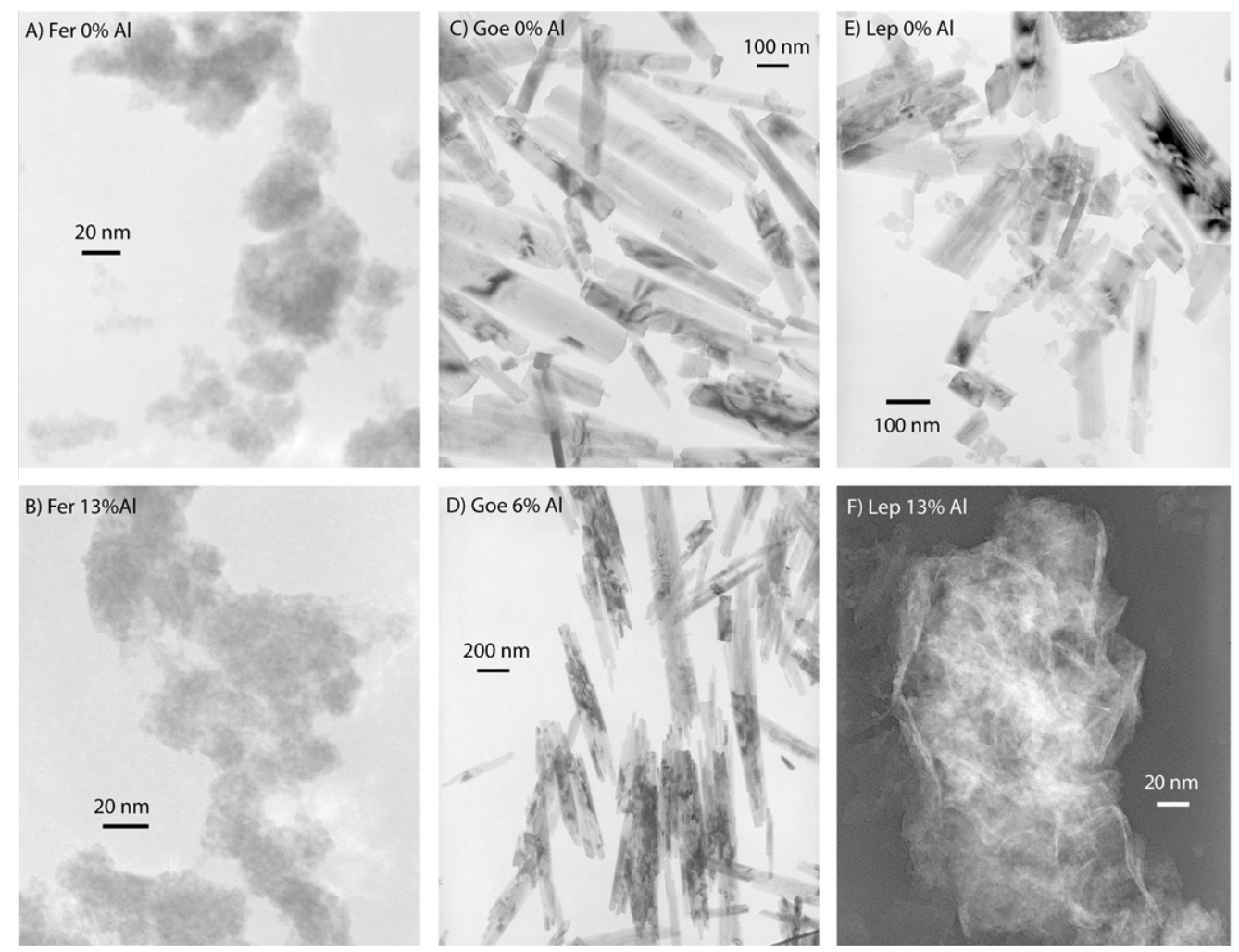

Fig. 4. Transmission electron microscopy (TEM) images of (A) $0 \%$ Al-ferrihydrite, (B) $13 \%$ Al-ferrihydrite, (C) $0 \%$ Al-goethite, (D) $6 \% \mathrm{Al}$ goethite, (E) 0\% Al-lepidocrocite, and (F) 13\% Al-lepidocrocite. Image (F) was inverted to enhance contrast, such that light areas indicate contrast from the $\mathrm{Fe}-\mathrm{Al}$ (hydr)oxides. In (A-E), dark areas represent contrast from the minerals.

required to reconstruct the EXAFS spectra approaching $65 \%$ for $13 \%$ Al-lepidocrocite (Supplementary information Table S1 and Fig. S5). Inclusion of ferrihydrite within the EXAFS fitting may be indicative of ferrihydrite impurities and/or regions of enhanced disorder within the lepidocrocite structure. In fact, trace amounts of small, sub-round spheres indicative of ferrihydrite were observed in the $0 \%$ Al-lepidocrocite sample (Supplementary information Fig. S3), while more grains indicative of a ferrihydrite-type phase were observed in 13\% Al-lepidocrocite (Fig. 4, Supplementary information Fig. S4, Table 2); yet, lepidocrocite remained the dominant phase consistent with the preservation of XRD lines (Fig. 1B) and EXAFS oscillations (Fig. 2) representative of lepidocrocite. Thus, a decrease in particle size and crystallinity and increase in ferrihydrite impurities are all likely contributing to the observed differences in the XRD and EXAFS spectra and acid dissolution behavior of lepidocrocite in response to $\mathrm{Al}$ substitution.

Although the goethite minerals were washed with hydroxylamine prior to analysis (Zachara et al., 2001), still, a disordered fraction (measured as ferrihydrite component) was required to fit the spectra using LC-EXAFS (Supplementary information Table 1 and Fig. S6). In contrast to lepidocrocite, increasing Al-substitution in goethite resulted in a slight decrease in the degree $(\%)$ of disorder, with the percent ferrihydrite in the fit decreasing from $22 \%(0 \%$ $\mathrm{Al})$ to $8 \%(6 \% \mathrm{Al})$. Maurice et al. (2000) also observed an increase in structural order with increasing Al substitution in goethite.

\subsection{Microbial Fe(III) (hydr)oxide reduction}

\subsubsection{Pure Fe(III) (hydr) oxides}

The synthesized Al-containing Fe(III) (hydr)oxides were used to explore the role that $\mathrm{Al}$ substitution has on the rates and extent of bacterial $\mathrm{Fe}(\mathrm{III})$ reduction by $S$. putrefaciens $\mathrm{CN} 32$. Iron(III) reduction rates (mmole $\mathrm{Fe}(\mathrm{II}) \mathrm{L}^{-1} \mathrm{~d}^{-1}$ ) were determined by calculating the rate of total $\mathrm{Fe}(\mathrm{II})$ production during the period of linear $\mathrm{Fe}(\mathrm{II})$ production coinciding with initial stages of the experiment. The period of linear $\mathrm{Fe}(\mathrm{II})$ production for ferrihydrite, lepidocrocite, and goethite was 13, 20, and 4 days, respectively. Rates were also calculated for acetate production over the same timeframe; yet, due to low respiration rates, acetate measurements were compromised by the high lactate background resulting in deviation from the expected $4: 1$ stoichiometry between $\mathrm{Fe}(\mathrm{II})$ and acetate generation. Furthermore, only soluble acetate was measured and therefore total acetate levels may be underestimated if acetate undergoes sorption to the Fe(III) (hydr)oxides.

As previously observed (Roden and Zachara, 1996), more crystalline $\mathrm{Fe}(\mathrm{III})$ (hydr)oxides are reduced at a slower rate (mmole $\mathrm{Fe}(\mathrm{II}) \mathrm{L}^{-1} \mathrm{~d}^{-1}$ ) than less crystalline phases such as ferrihydrite. Initial $\mathrm{Fe}$ (III) reduction rates of pure lepidocrocite and goethite were approximately half and one-third of pure ferrihydrite reduction rates, respectively (Fig. 5, Table 3). The lower rates of Fe(III) reduction for lepidocrocite and goethite resulted in a lower amount (\%) of $\mathrm{Fe}(\mathrm{III})$ (hydr)oxide reduced. After 20 days, 

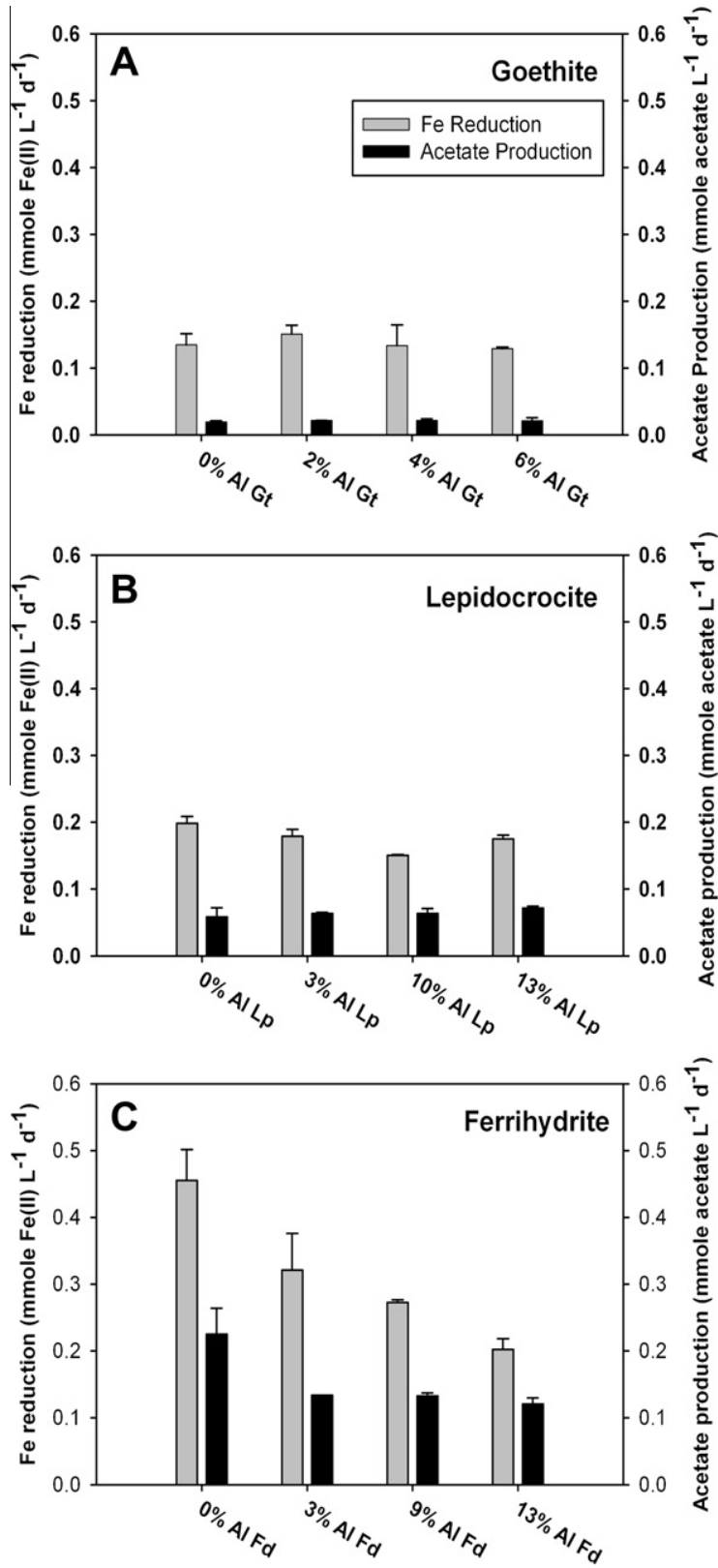

Fig. 5. Initial bacterial $\mathrm{Fe}(\mathrm{III})$ reduction rates and acetate production rates of goethite (A), lepidocrocite (B), and ferrihydrite (C) measured during the 20 day experiment. Error bars represent the standard deviation of duplicate microbial reduction assays.

S. putrefaciens reduced only $26.5 \%$ and $7.1 \%$ of the $\mathrm{Fe}(\mathrm{III})$ provided in lepidocrocite and goethite incubations, respectively, compared with $43.5 \%$ for ferrihydrite (Fig. 6, Table 3).

\subsubsection{Al-substituted Fe(III) (hydr) oxides}

Aluminum substitution within ferrihydrite, goethite and lepidocrocite had a variable effect on microbial $\mathrm{Fe}(\mathrm{III})$ reduction.

3.2.2.1. Goethite and lepidocrocite. Microbial Fe(III) reduction did not vary significantly with increasing Al substitu- tion for either lepidocrocite or goethite (Fig. 5A and B, Table 3). We did not observe a significant difference in $\mathrm{Fe}(\mathrm{III})$ reduction (single-factor ANOVA, $P=0.69$ ) or acetate production rates (single-factor ANOVA, $P=0.77$ ) as a function of $\mathrm{Al}$ substitution within goethite. Although the measured $\mathrm{Fe}(\mathrm{III})$ reduction rates for $10 \%$ Al-lepidocrocite are slightly lower than other treatments, there does not appear to be a consistent trend in response to Al substitution, and there is no significant difference in acetate production rates for the $\mathrm{Al}$ substituted lepidocrocite incubations (single-factor ANOVA, $P=0.51$ ). In addition, the amount $(\%)$ of $\mathrm{Fe}(\mathrm{II})$ produced after 20 days did not vary considerably for either the lepidocrocite or goethite series as a function of Al substitution (Fig. 6). Although only a small fraction of the goethite has been reduced (Fig. 6), microbial reduction ceases for both the pure and substituted phases following ca. 5 days (Fig. 7A) as observed previously (Hansel et al., 2004). In contrast, lepidocrocite reduction is ongoing at 20 days for both the pure and substituted phases (Fig. 7A). The majority of the $\mathrm{Fe}(\mathrm{II})$ produced remains in the aqueous phase for both goethite $(84 \%)$ and lepidocrocite $(87 \%)$ and is not significantly different as a function of Al substitution (83\% for 6\% Al-goethite and 93\% for 13\% Al-lepidocrocite).

Kukkadapu et al. (2001) found that bacterial Fe(III) reduction of a natural Al-substituted goethite containing 13-17 mol\% Al by S. putrefaciens CN32 did not occur at a significantly different rate relative to that of pure, synthetic goethite. In contrast, a $50 \%$ decrease in bacterial $\mathrm{Fe}(\mathrm{III})$ reduction was observed when an anaerobic fermenting bacterium, Clostridium butyricum, was grown with synthetic Al-goethite containing $5 \mathrm{~mol} \% \mathrm{Al}$ versus pure synthetic goethite (Bousserrhine et al., 1999). Furthermore, dissolution by $C$. butyricum was negatively correlated with the degree of $\mathrm{Al}$ substitution in goethite, ranging from 1.4 to $32 \mathrm{~mol} \%$ (Dominik et al., 2002). Other substituted cations (e.g., $\mathrm{Cr}$ ) were also found to decrease the bioreduction of goethite by C. butyricum (Bousserrhine et al., 1999). Yet, the cell population of the aerobic bacterium Pseudomonas mendocina growing on goethite increased with increasing Al substitution (Maurice et al., 2000). Although we performed our bioreduction experiments with Al-goethite minerals in the range of previous studies $(0-6 \mathrm{~mol} \% \mathrm{Al})$ (Bousserrhine et al., 1999; Dominik et al., 2002), we, like Kukkadapu et al. (2001) found no significant difference in $\mathrm{Fe}(\mathrm{III})$ reduction by $S$. putrefaciens $\mathrm{CN} 32$ for Al-containing goethite. Similarly, Ni and Co substitution does not significantly impact the reduction of goethite by $S$. putrefaciens CN32 (Zachara et al., 2001). Interestingly, the discrepancy of these findings may be due to the microorganism used in the incubations. In particular, $\mathrm{Al}$ and $\mathrm{Cr}$ impact the reduction of goethite by C. butyricum or P. mendocina, but Al, $\mathrm{Co}$, and $\mathrm{Ni}$ do not impact reduction by $S$. putrefaciens. While Fe(III) reduction by $S$. putrefaciens is performed for cellular respiration, it is unclear whether fermenting organisms conserve energy through $\mathrm{Fe}$ (III) reduction (Dobbin et al., 1999) or if $\mathrm{Fe}(\mathrm{III})$ (hydr)oxides act only as a supplementary terminal electron acceptor (Lovley, 1987). Furthermore, Pseudomonas mendocina is not capable of using $\mathrm{Fe}(\mathrm{III})$ as a terminal electron acceptor and instead 
Table 3

Summary of Fe reduction rates. ${ }^{\mathrm{a}}$

\begin{tabular}{|c|c|c|c|c|c|}
\hline Sample & $\begin{array}{l}\text { Fe reduction rate }{ }^{\mathrm{b}} \\
\text { mmole } \mathrm{Fe}(\mathrm{II}) \mathrm{L}^{-1} \mathrm{~d}^{-1}\end{array}$ & $\begin{array}{l}\text { Fe reduction rate } \\
\left(\text { mole } \mathrm{m}^{-2} \mathrm{~d}^{-1}\right)\end{array}$ & $\begin{array}{l}\text { Acetate production rate } \\
\left(\mathrm{mmole} \text { acetate } \mathrm{L}^{-1} \mathrm{~d}^{-1}\right)\end{array}$ & $\begin{array}{l}\text { Total Fe(II) } \\
(\mathrm{mM})\end{array}$ & $\begin{array}{l}\mathrm{Fe}(\mathrm{III}) \\
\text { reduced }(\%)\end{array}$ \\
\hline \multicolumn{6}{|c|}{ Bioreduction with slurry Fe oxide } \\
\hline $0 \%$ Al goethite & $0.135 \pm 0.016$ & $2.41 \times 10^{-6} \pm 3.43 \times 10^{-7}$ & $0.020 \pm 0.002$ & $1.27 \pm 0.03^{\mathrm{c}}$ & $7.1 \pm 0.2^{\mathrm{c}}$ \\
\hline $2 \% \mathrm{Al}$ goethite & $0.151 \pm 0.013$ & $2.49 \times 10^{-6} \pm 1.95 \times 10^{-7}$ & $0.022 \pm 0.000$ & $1.21 \pm 0.01^{\mathrm{c}}$ & $6.7 \pm 0.0^{\mathrm{c}}$ \\
\hline 4\% Al goethite & $0.134 \pm 0.031$ & $2.71 \times 10^{-6} \pm 6.06 \times 10^{-7}$ & $0.022 \pm 0.002$ & $1.09 \pm 0.06^{\mathrm{c}}$ & $6.1 \pm 0.3^{\mathrm{c}}$ \\
\hline $6 \% \mathrm{Al}$ goethite & $0.129 \pm 0.002$ & $2.91 \times 10^{-6} \pm 8.57 \times 10^{-8}$ & $0.021 \pm 0.004$ & $0.98 \pm 0.02^{\mathrm{c}}$ & $5.5 \pm 0.1^{\mathrm{c}}$ \\
\hline 3\% Al lepidocrocite & $0.179 \pm 0.010$ & $1.20 \times 10^{-6} \pm 6.03 \times 10^{-8}$ & $0.063 \pm 0.002$ & $4.57 \pm 0.24^{\mathrm{c}}$ & $25.5 \pm 1.3^{\mathrm{c}}$ \\
\hline $10 \%$ Al lepidocrocite & $0.150 \pm 0.001$ & $7.17 \times 10^{-7} \pm 1.63 \times 10^{-8}$ & $0.063 \pm 0.008$ & $4.24 \pm 0.15^{\mathrm{c}}$ & $23.7 \pm 0.8^{\mathrm{c}}$ \\
\hline $13 \%$ Al lepidocrocite & $0.175 \pm 0.006$ & $5.81 \times 10^{-7} \pm 2.80 \times 10^{-8}$ & $0.071 \pm 0.003$ & $4.71 \pm 0.22^{\mathrm{c}}$ & $26.3 \pm 1.2^{\mathrm{c}}$ \\
\hline $0 \%$ Al ferrihydrite & $0.455 \pm 0.046$ & $1.71 \times 10^{-6} \pm 1.74 \times 10^{-7}$ & $0.225 \pm 0.039$ & $7.79 \pm 0.01^{\mathrm{c}}$ & $43.5 \pm 0.1^{\mathrm{c}}$ \\
\hline $3 \%$ Al ferrihydrite & $0.321 \pm 0.055$ & $1.14 \times 10^{-6} \pm 1.98 \times 10^{-7}$ & $0.134 \pm 0.000$ & $5.58 \pm 0.59^{c}$ & $32.5 \pm 3.3^{\mathrm{c}}$ \\
\hline $9 \%$ Al ferrihydrite & $0.273 \pm 0.004$ & $1.07 \times 10^{-6} \pm 1.74 \times 10^{-8}$ & $0.133 \pm 0.004$ & $6.02 \pm 0.02^{\mathrm{c}}$ & $33.6 \pm 0.1^{\mathrm{c}}$ \\
\hline \multicolumn{6}{|c|}{ Bioreduction with sand-coated Fe oxide } \\
\hline $0 \%$ Al ferrihydrite & $0.136 \pm 0.023$ & N.A. & $0.070 \pm 0.009$ & $1.66 \pm 0.24^{\mathrm{d}}$ & $21.6 \pm 3.2^{\mathrm{d}}$ \\
\hline $3 \% \mathrm{Al}$ ferrihydrite & $0.100 \pm 0.012$ & N.A. & $0.056 \pm 0.001$ & $1.33 \pm 0.17^{\mathrm{d}}$ & $15.7 \pm 2.0^{\mathrm{d}}$ \\
\hline $9 \%$ Al ferrihydrite & $0.070 \pm 0.003$ & N.A. & $0.046 \pm 0.004$ & $1.00 \pm 0.01^{\mathrm{d}}$ & $12.5 \pm 0.1^{\mathrm{d}}$ \\
\hline $13 \%$ Al ferrihydrite & $0.042 \pm 0.014$ & N.A. & $0.015 \pm 0.005$ & $0.74 \pm 0.08^{\mathrm{d}}$ & $7.6 \pm 0.8^{\mathrm{d}}$ \\
\hline
\end{tabular}

N.A.: not available.

a Error bars represent the standard deviation of duplicate microbial reduction assays.

b Determined from linear production until day 4 for Gt, until day 20 for Lp, until day 13 for Fd, and until day 12 for Fd on sand.

c After 20.2 days.

d After 12.1 days.

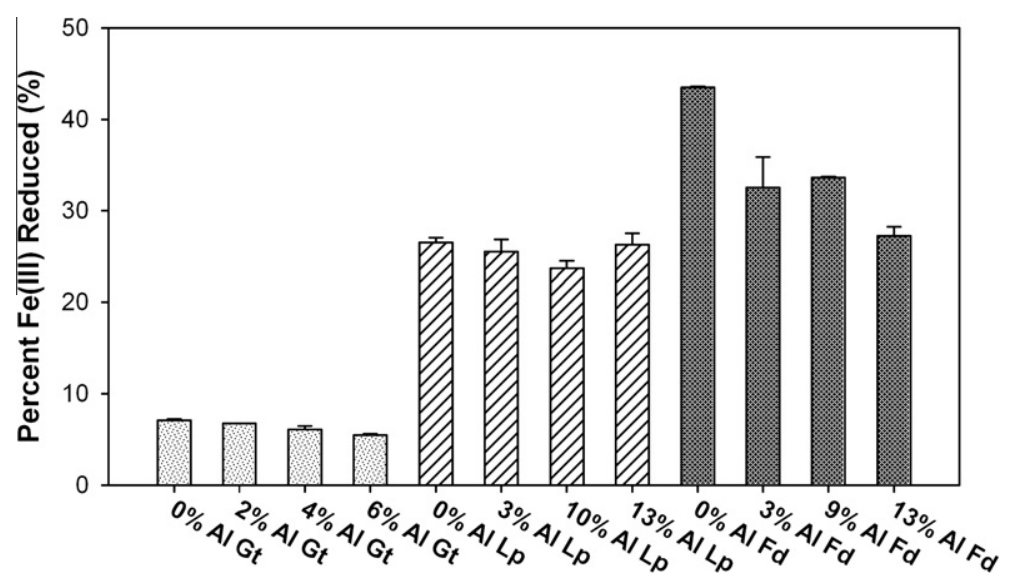

Fig. 6. Percent Fe(III) reduced with unsubstituted and substituted ferrihydrite (Fd), lepidocrocite (Lp), and goethite (Gd) at the end of the experiment, day 20. Error bars represent the standard deviation of duplicate microbial reduction assays.

the organism dissolves goethite to assimilate Fe (Maurice et al., 2000). Thus, the inhibitory impact of $\mathrm{Al}$ on $\mathrm{Fe}(\mathrm{III})$ reduction may be related to the mode of electron transfer or acquisition of $\mathrm{Fe}(\mathrm{III})$. To the best of our knowledge, the impact of $\mathrm{Al}$ substitution on lepidocrocite has not been previously investigated and thus this research is the first to illustrate that the bioreduction of lepidocrocite is not substantially impacted by $\mathrm{Al}$ incorporation.

3.2.2.2. Ferrihydrite. In contrast to Al-goethite and Al-lepidocrocite bioreduction, both initial $\mathrm{Fe}(\mathrm{III})$ reduction and acetate production rates significantly decreased with increasing $\mathrm{Al}$-substitution of ferrihydrite. $\mathrm{Fe}(\mathrm{III})$ reduction and acetate production rates of $13 \%$ Al-ferrihydrite assays were approximately half of those for $0 \%$ Al-ferrihydrite (Fig. 5C, Table 3). With declining Fe(III) reduction rates, the amount (\%) of $\mathrm{Fe}(\mathrm{III})$ (hydr)oxide reduced by $S$. putrefaciens grown on Al-substituted ferrihydrite also sequentially decreased (Fig. 6, Table 3). Cultures grown on $13 \%$ Al-ferrihydrite reduced only $27 \%$ of the $\mathrm{Fe}(\mathrm{III})$ (hydr)oxide present (Fig. 6, Table 3), which is comparable to the amount of lepidocrocite reduced. In contrast to lepidocrocite and goethite, however, the rate of $\mathrm{Fe}(\mathrm{II})$ production over time differs between pure and substituted ferrihydrite 

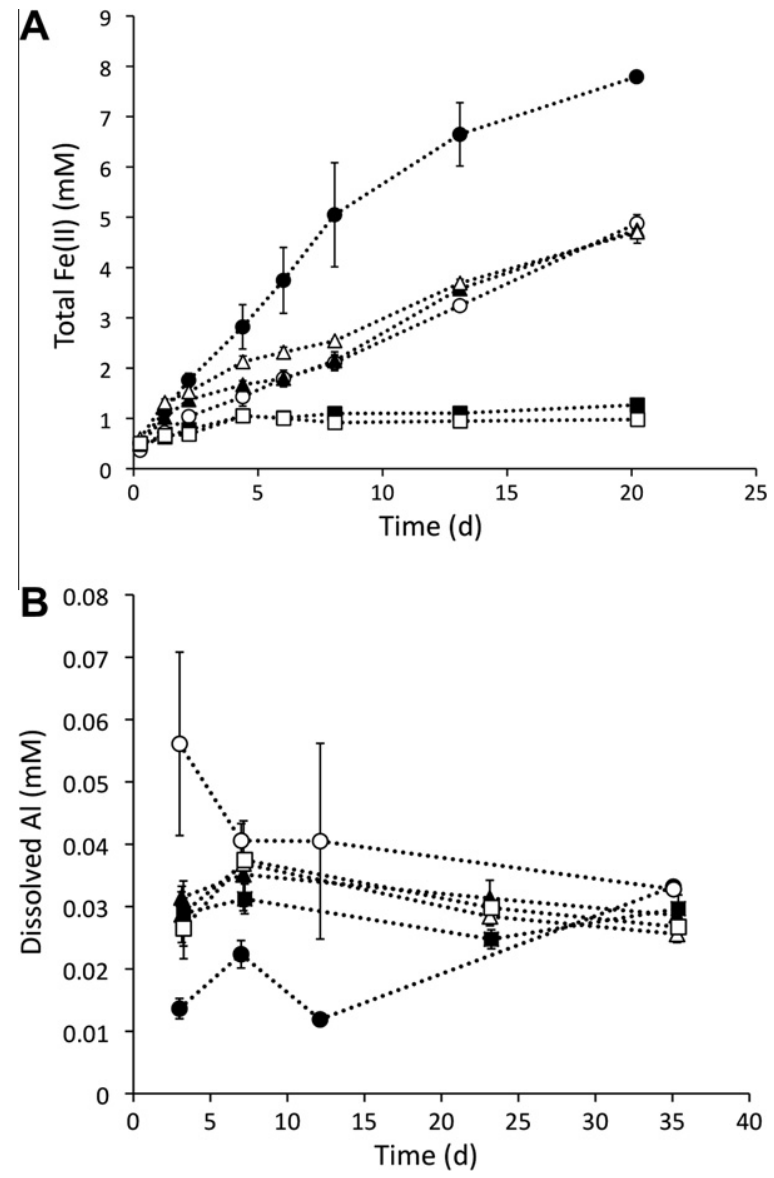

Fig. 7. Concentration of (A) total $\mathrm{Fe}(\mathrm{II})$ produced and (B) dissolved $\mathrm{Al}$ over time for pure (closed symbols) and substituted (open symbols) ferrihydrite (circles), lepidocrocite (triangles), and goethite (squares). The substituted phases illustrated are $13 \% \mathrm{Al}-$ ferrihydrite, 13\% Al-lepidocrocite, and 6\% Al-goethite. Total Fe(II) is representative of the dissolved $\mathrm{Fe}(\mathrm{II})$ concentrations since greater than $70 \%$ of the $\mathrm{Fe}(\mathrm{II})$ produced remains in solution. Dissolved $\mathrm{Al}$ concentrations were measured for a microbial reduction experiment conducted under identical conditions but run for 35 days. Error bars represent the standard deviation of duplicate microbial reduction assays.

(Fig. 7A). After 10 days, the rate of $\mathrm{Fe}(\mathrm{II})$ production declines for pure ferrihydrite, but does not change for $13 \%$ Al ferrihydrite. Thus, given sufficient time and assuming the rate does not change, the extent of $\mathrm{Fe}$ (III) reduction may become equivalent between the pure and substituted phases. The decline in ferrihydrite reduction may be in part a consequence of secondary mineralization of the ferrihydrite surface as observed previously (Hansel et al., 2004). While the partitioning of $\mathrm{Fe}(\mathrm{II})$ is equivalent between pure and substituted ferrihydrite phases, with only $11 \%$ of the total $\mathrm{Fe}(\mathrm{II})$ produced associated with the solid-phase, a greater degree of secondary mineralization is observed for pure ferrihydrite ( $32 \%$ ferrihydrite remains) relative to $13 \% \mathrm{Al}-$ ferrihydrite $(49 \%$ ferrihydrite remains; LC-EXAFS data not shown).

Although no previous work has determined the effect of Al substitution on bacterial ferrihydrite reduction, Fred- rickson et al. (2001) found that $5 \mathrm{~mol} \% \mathrm{Ni}$ substitution in ferrihydrite inhibited reduction by $S$. putrefaciens $\mathrm{CN} 32$. In contrast, Kukkadapu et al. (2004) found that 1 and $5 \mathrm{~mol} \% \mathrm{Si}$ substitution in ferrihydrite had no affect on $\mathrm{Fe}(\mathrm{III})$ reduction rates by $S$. putrefaciens $\mathrm{CN} 32$. Thus, the reduction of ferrihydrite by $S$. putrefaciens $\mathrm{CN} 32$ is inhibited by $\mathrm{Ni}$ and $\mathrm{Al}$ but not by $\mathrm{Si}$. It appears, therefore, that the impact of cation substitution on $\mathrm{Fe}$ (III) (hydr)oxide reduction is not only a function of the species of microorganism (as illustrated above for goethite) but also the type of cation incorporated into the structure.

While dissolved $\mathrm{Al}$ is known to be toxic to bacteria at elevated concentrations (Illmer and Schinner, 1997; Amonette et al., 2003), only a minor fraction of the solid Al became soluble, reaching concentrations of $12-56 \mu \mathrm{M}$ (Fig. 7B), well below what has been shown to impact bacterial growth (Amonette et al., 2003). Furthermore, while $13 \% \mathrm{Al}$ substitution within ferrihydrite had the greatest effect on bacterial reduction, the concentration of soluble $\mathrm{Al}$ is lowest for this phase (Fig. 7B). In contrast to the chemical dissolution results (Fig. 3), the bacterial induced dissolution of $\mathrm{Fe}$ and $\mathrm{Al}$ is incongruent (Fig. 7B) as observed previously for microbial reduction of synthetic (Bousserrhine et al., 1999; Dominik et al., 2002) and natural goethites (Kukkadapu et al., 2001). Thus, Al released during bioreduction is likely adsorbing or precipitating on the $\mathrm{Fe}(\mathrm{III})$ (hydr)oxide surfaces. Dominik et al. (2002) determined that the majority $(80-93 \%)$ of $\mathrm{Al}$ released during reduction of Al-substituted goethites by $C$. butyricum was associated with the solid-phase and suggested that this may inhibit further microbial reduction. Here, considering that only ferrihydrite shows an inhibition of microbial reduction in the presence of $\mathrm{Al}$, however, suggests that other factors impacting bioreduction must also be operative.

Given the substantial effect that Al substitution plays in the rate and extent of microbial reduction of ferrihydrite, which is considered the most bioavailable Fe(III) (hydr)oxide in sediments, we wanted to further explore the impact of $\mathrm{Al}$ on ferrihydrite reduction rates under conditions more representative of natural environments, where Fe(III) (hydr)oxides typically exist as coatings on soil particles (Cornell and Schwertmann, 2003). Rates of reduction of ferrihydrite-coated quartz sand by $S$. putrefaciens strain CN32 significantly decreased with increasing Al substitution, consistent with the ferrihydrite slurry experiments (Table 3 ). The overall rate of $\mathrm{Fe}(\mathrm{III})$ reduction of the ferrihydrite-coated sand, however, was lower than those for the slurry incubations, with $\mathrm{Fe}(\mathrm{III})$ reduction rates on average $70 \%$ lower than those measured in slurry. Although our rates are much lower than those measured in continuous flow conditions (Hansel et al., 2004), Roden et al. (2000) measured comparable $\mathrm{Fe}(\mathrm{III})$ reduction rates in batch experiments with Fe(III) (hydr)oxide-coated sand.

\subsection{Mineralogical controls on bacterial Fe reduction}

Variability in the rates of $\mathrm{Fe}(\mathrm{III})$ reduction by DIRB have previously been linked to surface area, solubility, mineral structure, particle size, and crystallinity (Roden and Zachara, 1996; Neal et al., 2003; Glasauer et al., 2003; 


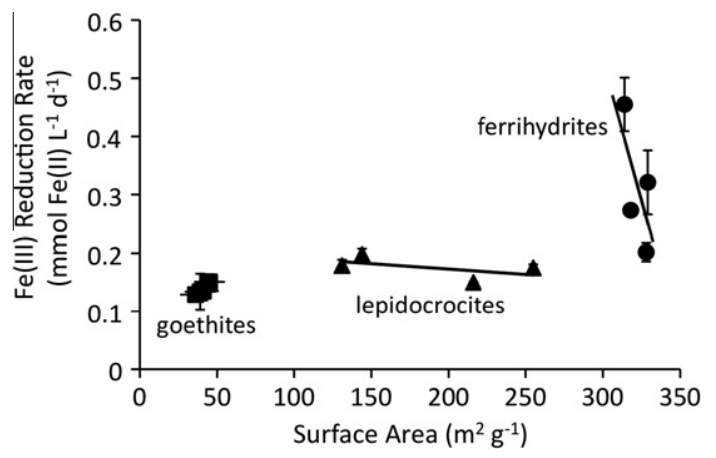

Fig. 8. Relationship between microbial Fe(III) reduction rate (mmole $\mathrm{Fe}(\mathrm{II}) \mathrm{L}^{-1} \mathrm{~d}^{-1}$ ) and surface area $\left(\mathrm{m}^{2} \mathrm{~g}^{-1}\right.$ ) for ferrihydrite (circles), goethite (squares), and lepidocrocite (triangles). Error bars represent the standard deviation of duplicate microbial reduction assays.

Cutting et al., 2009; Bonneville et al., 2009). Here, we do not observe a direct correlation between surface area, particle size, degree of structural order, or abiotic dissolution rates of the minerals with the observed $\mathrm{Fe}(\mathrm{III})$ bioreduction rates for each mineral type. Unlike previous studies comparing pure $\mathrm{Fe}(\mathrm{III})$ (hydr)oxides (Roden and Zachara, 1996; Roden, 2006), we do not observe a correlation between surface area and Fe(III) reduction rates (Fig. 8). Instead, normalizing the $\mathrm{Fe}(\mathrm{III})$ reduction rates by surface area did not change the trends in the rates of reduction of ferrihydrite and goethite as a function of $\mathrm{Al}$ substitution (Table 3). In fact, although Al substitution caused a substantial increase in surface area for 10\% and 13\% Al lepidocrocite (Table 2), the rate of $\mathrm{Fe}(\mathrm{III})$ reduction (mmole $\mathrm{L}^{-1} \mathrm{~d}^{-1}$ ) did not differ - thus, surface area normalized $\mathrm{Fe}(\mathrm{III})$ reduction rates were lower for lepidocrocite with higher amounts of substitution (10\% and 13\% Al) compared to lower levels of substitution $(0 \%$ and $3 \% \mathrm{Al})$ (Table 3).

With increasing $\mathrm{Al}$ substitution, the dissolution rate (Table 1), surface area (Table 2), and structural disorder (Supplementary information Table S1) decreased for goethite although we observe no significant change in Fe(III) reduction rates (Table 3). Furthermore, structural and morphological differences are observed as a function of $\mathrm{Al}$ substitution in goethite (Fig. 4C and D, Supplementary information Table S1), yet this does not appear to influence the rate and extent of goethite reduction. We also do not see significant differences in the extent and rate of lepidocrocite reduction with increasing $\mathrm{Al}$ content, even though acid dissolution rates (Table 1) and surface area (Table 2) increase substantially. Also, the increased presence of ferrihydrite and likely structural disorder (Figs. 1, 2 and 4 and Supplementary information Table S1) do not substantially impact the rate and extent of reduction. In contrast to lepidocrocite, however, the dissolution behavior (Table 1), surface area and size (Table 2) of ferrihydrite are not substantially impacted by Al substitution, yet we see significant differences in $\mathrm{Fe}$ (III) reduction rates. It is therefore unclear at this point what mineralogical parameters control the differences in $\mathrm{Fe}(\mathrm{III})$ reduction among the $\mathrm{Fe}(\mathrm{III})$ minerals.
Recently, solubility (Bonneville et al., 2009) and crystallinity (Cutting et al., 2009) have been convincingly linked to the reduction rates of various $\mathrm{Fe}$ (III) (hydr)oxides and may be controlling variables here. In fact, $\mathrm{Si}$ incorporation in ferrihydrite reduces $\mathrm{Fe}$ double corner linkages, which may impact reactivity and be responsible for a lack of ferrihydrite transformation to secondary phases upon reaction with aqueous Fe(II) (Jones et al., 2009). Here, however, we do not observe changes in the Fe-Fe double corner contribution ( $\sim 7.5 \AA$ in Fig. 2$)$ with increasing $\mathrm{Al}$ content in ferrihydrite. Yet, preliminary EXAFS analysis suggests that the $\mathrm{Fe}$ coordination and $\mathrm{Fe}-\mathrm{O}$ distances are impacted by the incorporation of $\mathrm{Al}$ within the structure (data not shown); a detailed structural refinement for the Fe(III) (hydr)oxides is underway. Structural differences may influence electron transfer, for instance, by changing the solubility and (micro) crystallinity of the phases. The impact of $\mathrm{Al}$ on the electrical properties (e.g., reduction potential) of the phases also needs to be fully explored.

\section{ENVIRONMENTAL IMPLICATIONS}

Faster $\mathrm{Fe}(\mathrm{III})$ reduction rates of ferrihydrite compared to more crystalline $\mathrm{Fe}(\mathrm{III})$ (hydr)oxides (Roden and Zachara, 1996; Glasauer et al., 2003; Hansel et al., 2004) has implicated ferrihydrite as the most bioavailable, and hence important, $\mathrm{Fe}$ (III) phase for microbial respiration (Lovley and Phillips, 1986). However, Fe(III) (hydr)oxides are rarely pure in nature, and are often co-precipitated with Al (Cornell and Schwertmann, 2003). We have found that increasing concentrations of $\mathrm{Al}$ in ferrihydrite results in decreasing microbial $\mathrm{Fe}(\mathrm{III})$ reduction, yet Al-substitution has no effect on $\mathrm{Fe}(\mathrm{III})$ reduction in goethite and lepidocrocite minerals. By plotting the $\mathrm{Fe}(\mathrm{III})$ reduction rates versus mol\% Al (Fig. 9), we can extrapolate the possible effects of $\mathrm{Al}$ at higher concentrations. As Al substitution increases, the rates of $\mathrm{Fe}(\mathrm{III})$ reduction for ferrihydrite begin to converge with those for lepidocrocite and goethite. Based on projected rates, at molar concentrations above $18 \%$, the rate of ferrihydrite reduction would be less than that of both lepidocrocite and goethite. Also, interestingly, the amount $(\%)$ of $\mathrm{Fe}(\mathrm{III})$ reduction consistently declines $2 \%$ for every $\mathrm{mol} \%$ increase in $\mathrm{Al}$ substitution in ferrihydrite.

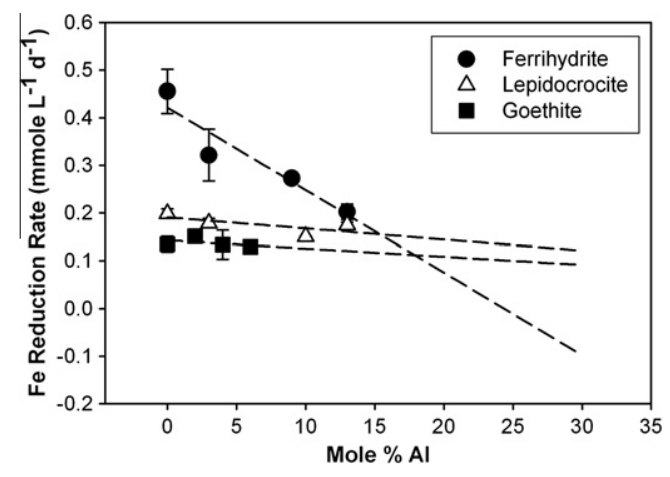

Fig. 9. Bacterial $\mathrm{Fe}(\mathrm{III})$ reduction rate versus $\mathrm{mol} \% \mathrm{Al}$ for ferrihydrite (closed circles), lepidocrocite (open triangles), and goethite (closed squares). Error bars represent the standard deviation of duplicate microbial reduction assays. 
We have successfully synthesized ferrihydrite containing $24 \mathrm{~mol} \% \mathrm{Al}$ without formation of separate Al phases, which would be far less reactive than both lepidocrocite and goethite (Fig. 9). Given the predominance of Al substitution in natural $\mathrm{Fe}$ (hydr)oxides, the bioavailability of ferrihydrite in soils and sediments to DIRB needs to be revisited. Alternatively, since lepidocrocite and goethite reduction is not impacted by $\mathrm{Al}$ substitution, these more crystalline Fe (hydr)oxides could play a more important role in sustaining the metabolism of $\mathrm{Fe}(\mathrm{III})$-reducing bacteria in nature than currently thought (van der Zee et al., 2003).

Within mature soils and sediments, the preservation of ferrihydrite will be a function of $\mathrm{Al}$ (or other cation) substitution, which, as we demonstrate here, decreases its bioavailability and makes more crystalline phases the preferential electron acceptor. In fact, a number of current studies have identified Al-substituted goethite and phyllosilicates as the primary terminal electron acceptors used by $\mathrm{Fe}(\mathrm{III})$-reducing microorganisms in contaminated subsurface sediments (Kukkadapu et al., 2006; Stucki et al., 2007; Komlos et al., 2008). Thus, in situ bioremediation of metals (e.g., Cr, U, Tc) via generation of the reductant Fe(II) (Senko et al., 2002; North et al., 2004; Stucki et al., 2007) may be controlled by microbial reduction of crystalline $\mathrm{Fe}(\mathrm{III})$ (hydr)oxides and clays rather than phases routinely considered more bioavailable (e.g., ferrihydrite). Thus, further exploration of the role of $\mathrm{Al}$ substitution on microbial Fe(III) reduction will greatly enhance our ability to predict the reducing capacity of sediments and design $\mathrm{Fe}(\mathrm{II})$-based remediation approaches.

\section{ACKNOWLEDGMENTS}

We thank Christopher Lentini, Cassandra Freyschlag, Jane Ng, Greta Friar, Greg Eischeid, William Croft, Greg Strout, and James Cooley for technical assistance. We also appreciate the constructive comments from three anonymous reviewers, which greatly improved this manuscript. X-ray absorption spectroscopy was carried out at the Stanford Synchrotron Radiation Laboratory, a national user facility operated by Stanford University on behalf of the U.S. Department of Energy, Office of Basic Energy Sciences. The SSRL Structural Molecular Biology Program is supported by the Department of Energy, Office of Biological and Environmental Research, and the National Institutes of Health, National Center for Research Resources, Biomedical Technology Program.

\section{APPENDIX A. SUPPLEMENTARY DATA}

Supplementary data associated with this article can be found, in the online version, at doi:10.1016/ j.gca.2010.09.008.

\section{REFERENCES}

Ainsworth C. C., Girvin D. C., Zachara J. M. and Smith S. C. (1989) Chromate adsorption on goethite: effects of aluminum substitution. Soil Sci. Soc. Am. 53, 411-418.

Alvarez M., Rueda E. H. and Sileo E. (2007) Simultaneous incorporation of $\mathrm{Mn}$ and $\mathrm{Al}$ in the goethite structure. Geochim. Cosmochim. Acta 71, 1009-1020.
Amonette J. E., Russell C. K., Carosino K. A., Robinson N. L. and Ho J. T. (2003) Toxicity of Al to Desulfovibrio desulfuricans. Appl. Environ. Microbiol. 69, 4057-4066.

Behrends T. and Van Cappellen P. (2007) Transformation of hematite into magnetite during dissimilatory iron reductionconditions and mechanisms. Geomicrobiol. J. 24, 403-416.

Benner S. G., Hansel C. M., Wielinga B. W., Barber T. M. and Fendorf S. (2002) Reductive dissolution and biomineralization of iron hydroxide under dynamic flow conditions. Environ. Sci. Technol. 36, 1705-1711.

Bonneville S., Behrends T. and Van Cappellen P. (2009) Solubility and dissimilatory reduction kinetics of iron(III) oxyhydroxides: a linear free energy relationship. Geochim. Cosmochim. Acta 73, 5273-5282.

Bose S., Hochella, Jr., M. F., Gorby Y. A., Kennedy D. W., McCready D. E., Madden A. S. and Lower B. H. (2009) Bioreduction of hematite nanoparticles by the dissimilatory iron reducing bacterium Shewanella oneidensis MR-1. Geochim. Cosmochim. Acta 73, 962-976.

Bousserrhine N., Gasser U. G., Jeanroy E. and Berthelin J. (1999) Bacterial and chemical reductive dissolution of Mn-, Co-, Cr-, and Al-substituted goethites. Geomicrobiol. J. 16, 245-258.

Bretschger O., Obraztsova A., Sturm C. A., Chang I. S., Gorby Y. A., Reed S. B., Culley D. E., Reardon C. L., Barua S., Romine M. F., Zhou J., Beliaev A. S., Bouhenni R., Saffarini D., Mansfeld F., Kim B.-H., Fredrickson J. K. and Nealson K. H. (2007) Current production and metal oxide reduction by Shewanella oneidensis MR-1 wild type and mutants. Appl. Environ. Microbiol. 73, 7003-7012.

Brooks S. C., Taylor D. L. and Jardine P. M. (1996) Reactive transport of EDTA-complexed cobalt in the presence of ferrihydrite. Geochim. Cosmochim. Acta 60, 1899-1908.

Cornell R. M. and Schwertmann U. (2003) The Iron Oxides: Structure, Properties, Reactions, Occurrences, and Uses. Wiley$\mathrm{VCH}$.

Cornell R. M., Posner A. M. and Quirk J. P. (1974) Crystal morphology and the dissolution of goethite. J. Inorg. Nucl. Chem. 36, 1937-1946.

Cutting R. S., Coker V. S., Fellowes J. W., Lloyd J. R. and Vaughan D. J. (2009) Mineralogical and morphological constraints on the reduction of $\mathrm{Fe}(\mathrm{III})$ minerals by Geobacter sulfurreducens. Geochim. Cosmochim. Acta 73, 4004-4022.

DiChristina T. M., Hoffman M., Arnold R. G. and Lidstrom M. E. (1988) Dissimilative Fe(III) reduction by the marine eubacterium Alteromonas putrefaciens 200. Water Sci. Technol. 20, 69 79.

Dobbin P. S., Carter J. P., San Juan C. G.-S., von Hobe M., Powell A. K. and Richardson D. J. (1999) Dissimilatory Fe(III) reduction by Clostridium beijerinckii isolated from freshwater sediment using $\mathrm{Fe}(\mathrm{III})$ maltol enrichment. FEMS Microbiol. Lett. 176, 131-138.

Dominik P., Pohl H. N., Bousserrhine N., Berthelin J. and Kaupenjohann M. (2002) Limitations to the reductive dissolution of Al-substituted goethites by Clostridium butyricum. Soil Biol. Biochem. 34, 1147-1155.

Fredrickson J. K., Kota S., Kukkadapu R. K., Liu C. and Zachara J. M. (2003) Influence of electron donor/acceptor concentrations on hydrous ferric oxide biodegradation. Biodegradation 14, 91-103.

Fredrickson J. K., McKinley J. P., Bjornstad B. N., Ringelberg D. B., White D. C., Krumholz L. R., Sulfita J. M., Colwell F. S., Lehman R. M. and Phelps T. J. (1997) Pore-size constraints on the activity and survival of subsurface bacteria in a late Cretaceous shale-sandstone sequence, northwestern New Mexico. Geomicrobiol. J. 14, 183-202. 
Fredrickson J. K., Zachara J. M., Kennedy D. W., Dong H., Onstott T., Hinman N. W. and Li S.-M. (1998) Biogenic iron mineralization accompanying the dissimilatory reduction of hydrous ferric oxide by a groundwater bacterium. Geochim. Cosmochim. Acta 62, 3239-3257.

Fredrickson J. K., Zachara J. M., Kukkadapu R. K., Gorby Y. A., Smith S. C. and Brown C. F. (2001) Biotransformation of Nisubstituted hydrous ferric oxide by an $\mathrm{Fe}(\mathrm{III})$-reducing bacterium. Environ. Sci. Technol. 35, 703-712.

Glasauer S., Weidler P. G., Langley S. and Beveridge T. J. (2003) Controls on $\mathrm{Fe}$ reduction and mineral formation by a subsurface bacterium. Geochim. Cosmochim. Acta 67, 1277-1288.

Gonzalez E., Ballesteros M. C. and Rueda E. H. (2002) Reductive dissolution kinetics of Al-substituted goethites. Clays Clay Miner. 50, 470-477.

Hansel C. M., Benner S. G., Neiss J., Dohnalkova A., Kukkadapu R. K. and Fendorf S. (2003) Secondary mineralization pathways induced by dissimilatory iron reduction of ferrihydrite under advective flow. Geochim. Cosmochim. Acta 67, 29772992.

Hansel C. M., Benner S. G., Nico P. and Fendorf S. (2004) Structural constrains of ferric (hydr)oxides on dissimilatory iron reduction and the fate of $\mathrm{Fe}(\mathrm{II})$. Geochim. Cosmochim. Acta 68, 3217-3229.

Illmer P. and Schinner F. (1997) Influence of aluminum on motility and swarming of Pseudomonas sp. and Arthrobacter sp. FEMS Microbiol. Lett. 155, 121-124.

Jones A. M., Collins R. N., Rose J. and Waite T. D. (2009) The effect of silica and natural organic matter on the $\mathrm{Fe}$ (II)catalyzed transformation and reactivity of $\mathrm{Fe}(\mathrm{III})$ minerals. Geochim. Cosmochim. Acta 73, 4409-4422.

Kabai J. (1973) Determination of specific activation energies of metal oxides and metal oxide hydrates by measurement of the rate of dissolution. Acta Chim. Acad. Sci. Hung. 78, 57-73.

Kassim J., Baird T. and Fryer J. R. (1982) Electron microscope studies of iron corrosion products in water at room temperature. Corros. Sci. 22, 147-158.

Komlos J., Peacock A., Kukkadapu R. K. and Jaffe P. R. (2008) Long-term dynamics of uranium reduction/reoxidation under low sulfate conditions. Geochim. Cosmochim. Acta 72, 36033615.

Kukkadapu R. K., Zachara J. M., Fredrickson J. K., McKinley J. P., Kennedy D. W., Smith S. C. and Dong H. (2006) Reduction biotransformation of $\mathrm{Fe}$ in shale-limestone saprolite containing $\mathrm{Fe}(\mathrm{III})$ oxides and $\mathrm{Fe}(\mathrm{II}) / \mathrm{Fe}(\mathrm{III})$ phyllosilicates. Geochim. Cosmochim. Acta 70, 3662-3676.

Kukkadapu R. K., Zachara J. M., Fredrickson J. K. and Kennedy D. W. (2004) Biotransformation of two-line silica-ferrihydrite by a dissimilatory $\mathrm{Fe}(\mathrm{III})$-reducing bacterium: formation of carbonate green rust in the presence of phosphate. Geochim. Cosmochim. Acta 68, 2799-2814.

Kukkadapu R. K., Zachara J. M., Smith S. C., Fredrickson J. K. and Liu C. (2001) Dissimilatory bacterial reduction of Alsubstituted goethite in subsurface sediments. Geochim. Cosmochim. Acta 65, 2913-2924.

Lloyd J. R. (2003) Microbial reduction of metals and radionuclides. FEMS Microbiol. Rev. 27, 411-425.

Lovley D. R. (1987) Organic-matter mineralization with the reduction of ferric iron - a review. Geomicrobiol. J. 5, 375-399.

Lovley D. R. (1997) Potential for anaerobic bioremediation of BTEX in petroleum-contaminated aquifers. J. Ind. Microbiol. 18, 75-81.

Lovley D. R. (2008) Extracellular electron transfer: wires, capacitors, iron lungs, and more. Geobiology 6, 225-231.

Lovley D. R., Baedecker M. J., Lonergan D. J., Cozzarelli I. M., Phillips E. J. P. and Siegel D. I. (1989) Oxidation of aromatic contaminants coupled to microbial iron reduction. Nature 339, 297-299.

Lovley D. R. and Phillips E. J. P. (1986) Availability of ferric iron for microbial reduction in bottom sediments of the freshwater tidal Potomac River. Appl. Environ. Microbiol. 52, 751-757.

Lovley D. R., Stolz J. F., Nord G. L. and Phillips E. J. P. (1987) Anaerobic production of magnetite by a dissimilatory ironreducing microorganism. Nature 330, 252-254.

Masue Y., Loeppert R. H. and Kramer T. A. (2007) Arsenate and arsenite adsorption and desorption behavior on coprecipitated aluminum:iron hydroxides. Environ. Sci. Technol. 41, 837-842.

Maurice P. A., Lee Y.-J. and Hersman L. E. (2000) Dissolution of Al-substituted goethites by an aerobic Pseudomonas mendocina var. bacteria. Geochim. Cosmochim. Acta 64, 1363-1374.

Neal A. L., Rosso K. M., Geesey G. G., Gorby Y. A. and Little B. J. (2003) Surface structure effects on direction reduction of iron oxides by Shewanella oneidensis. Geochim. Cosmochim. Acta 67, 4489-4503.

North N. N., Dollhopf S. L., Petrie L., Istok J. D., Balkwill D. L. and Kostka J. E. (2004) Change in bacterial community structure during in situ biostimulation of subsurface sediment cocontaminated with uranium and nitrate. Appl. Environ. Microbiol. 70, 4911-4920.

Ona-Nguema G., Abdelmoula M., Jorand F., Benali O., Gehin A., Block J.-C. and Genin J.-M. R. (2002) Microbial reduction of lepidocrocite $\gamma$-FeOOH by Shewanella putrefaciens; the formation of green rust. Hyperfine Interact. 139(140), 231-237.

Ona-Nguema G., Carteret C., Benali O., Abdelmoula M., Genin J.M. and Jorand F. (2004) Competitive formation of hydroxycarbonate green rust 1 versus hydroxysulfate green rust 2 in Shewanella putrefaciens cultures. Geomicrobiol. J. 21, 79-90.

Roden E. E. (2006) Geochemical and microbiological controls on dissimilatory iron reduction. C.R. Geosci. 338, 456-467.

Roden E. E. and Zachara J. M. (1996) Microbial reduction of crystalline iron(III) oxides: influence of oxide surface area and potential for cell growth. Environ. Sci. Technol. 30, 1618-1628.

Roden E. E., Urrutia M. M. and Mann C. J. (2000) Bacterial reductive dissolution of crystalline $\mathrm{Fe}(\mathrm{III})$ oxide in continuousflow column reactors. Appl. Environ. Microbiol. 66, 1062-1065.

Schulze D. G. and Schwertmann U. (1984) The influence of aluminum on iron oxides. X: Properties of Al-substituted goethites. Clay Miner. 19, 521-529.

Schulze D. G. and Schwertmann U. (1987) The influence of aluminum on iron oxides. XIII: Properties of goethites synthesized in $0.3 \mathrm{M} \mathrm{KOH}$ at $25^{\circ} \mathrm{C}$. Clay Miner. 22, 83-92.

Schwertmann U. (1984) The influence of aluminum on iron oxides. IX: Dissolution of Al-goethites in $6 \mathrm{M} \mathrm{HCl}$. Clay Miner. 19, 919.

Schwertmann U., Cambier P. and Murad E. (1985) Properties of goethites of varying crystallinity. Clays Clay Miner. 33, 369378.

Schwertmann U. (1991) Solubility and dissolution of iron oxides. Plant Soil. 130, 1-25.

Schwertmann U. and Cornell R. M. (2000) Iron Oxides in the Laboratory: Preparation and Characterization. Wiley-VCH.

Schwertmann U. and Wolska E. (1990) The influence of aluminum on iron oxides. XV: Al-for-Fe substitution in synthetic lepidocrocite. Clays Clay Miner. 38, 209-212.

Senko J. M., Istok J. D., Suflita J. M. and Krumholz L. R. (2002) In-situ evidence for uranium immobilization and remobilization. Environ. Sci. Technol. 36, 1491-1496.

Stookey L. L. (1970) Ferrozine-a new spectrometric reagent for iron. Anal. Chem. 42, 779-781.

Stucki J. W., Lee K., Goodman B. A. and Kostka J. E. (2007) Effects of in situ biostimulation on iron mineral speciation in a sub-surface soil. Geochim. Cosmochim. Acta 71, 835-843. 
Straub K. L., Kappler A. and Schink B. (2005) Enrichment and isolation of ferric-iron- and humic-acid-reducing bacteria. Methods Enzymol. 397, 58-77.

Taylor R. M. and Schwertmann U. (1980) The influence of aluminum on iron oxides. VII: Substitution of $\mathrm{Al}$ for $\mathrm{Fe}$ in synthetic lepidocrocite. Clays Clay Miner. 28, 267-271.

Torrent J., Schwertmann U. and Barron V. (1987) The reductive dissolution of synthetic goethite and hematite in dithionite. Clays Clay Miner. 22, 329-337.

Trolard F. and Tardy Y. (1987) The stabilities of gibbsite, boehmite, aluminous goethites and aluminous hematites in bauxites, ferricretes, and laterites as a function of water activity, temperature, and particle size. Geochim. Cosmochim. Acta 51, 945-957.

van der Zee C., Roberts D. R., Rancourt D. G. and Slomp C. P. (2003) Nanogoethite is the dominant reactive oxyhydroxide phase in lake and marine sediments. Geology 31, 993-996.

Wang M. K., Chang C. M., Cheng Y. W., Houng K. H. and Chiang H. C. (1999) Comparison of synthetic and soil Alsubstituted lepidocrocite. Soil Sci. 164, 311-321.

Webb S. M. (2005) SIXpack: a graphical user interface for XAS analysis using IFEFFIT. Phys. Scr. T115, 1011-1014.
Widdel F. and Bak F. (1992) Gram-negative mesophilic sulfate reducing bacteria. In The Prokaryotes (eds. A. Balows, H. G. Truper, M. Dworkin, W. Harder and K.-H. Schleifer), 2nd ed. Springer-Verlag, New York, pp. 3352-3378.

Wilkins M. J., Livens F. R., Vaughan D. J. and Lloyd J. R. (2006) The impact of $\mathrm{Fe}(\mathrm{III})$-reducing bacteria on uranium mobility. Biogeochemistry 78, 125-150.

Wilkins M. J., Wincott P. L., Vaughan D. J., Livens F. R. and Lloyd J. R. (2007) Growth of Geobacter sulfurreducens on poorly crystalline $\mathrm{Fe}(\mathrm{III})$ oxyhydroxide coatings. Geomicrobiology 24, 199-204.

Zachara J. M., Fredrickson J. K., Smith S. C. and Gassman P. L. (2001) Solubilization of Fe(III) oxide-bound trace metals by a dissimilatory $\mathrm{Fe}(\mathrm{III})$ reducing bacterium. Geochim. Cosmochim. Acta 65, 75-93.

Zachara J. M., Kukkadapu R. K., Fredrickson J. K., Gorby Y. A. and Smith S. C. (2002) Biomineralization of poorly crystalline $\mathrm{Fe}(\mathrm{III})$ oxides by dissimilatory metal reducing bacteria (DMRB). Geomicrobiol. J. 19, 179-207.

Associate editor: Kevin M. Rosso 